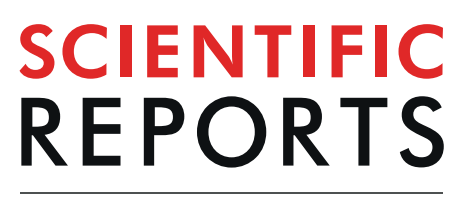

natureresearch

\title{
OPEN Up-regulation of voltage-gated sodium channels by peptides mimicking S4-S5 linkers reveals a variation of the ligand-receptor mechanism
}

\begin{abstract}
Olfat A. Malak $k^{1,2,6}$, Fayal Abderemane-Ali ${ }^{1,3,6}$, Yue Wei $^{1,4}$, Fabien C. Coyan ${ }^{1}$, Gilyane Pontus ${ }^{1}$, David Shaya ${ }^{5}$, Céline Marionneau ${ }^{1} \&$ Gildas Loussouarn $\left(10^{1 *}\right.$

Prokaryotic $\mathrm{Na}_{v}$ channels are tetramers and eukaryotic $\mathrm{Na}_{v}$ channels consist of a single subunit containing four domains. Each monomer/domain contains six transmembrane segments (S1-S6), S1-S4 being the voltage-sensor domain and S5-S6 the pore domain. A crystal structure of $\mathrm{Na}_{v} \mathrm{Ms}$, a prokaryotic $\mathrm{Na}_{V}$ channel, suggests that the $\mathrm{S} 4-\mathrm{S} 5$ linker $\left(\mathrm{S} 4-\mathrm{S} 5_{\mathrm{L}}\right.$ ) interacts with the C-terminus of $\mathrm{S} 6$ $\left(\mathrm{S}_{\mathrm{T}}\right)$ to stabilize the gate in the open state. However, in several voltage-gated potassium channels, using specific $\mathrm{S} 4-\mathrm{S} 5_{\mathrm{L}}-$-mimicking peptides, we previously demonstrated that $\mathrm{S} 4-\mathrm{S} 5_{\mathrm{L}} / \mathrm{S} \mathrm{S}_{\mathrm{T}}$ interaction stabilizes the gate in the closed state. Here, we used the same strategy on another prokaryotic $\mathrm{Na}_{\mathrm{V}}$ channel, $\mathrm{Na}_{\mathrm{V}} \mathrm{Sp} 1$, to test whether equivalent peptides stabilize the channel in the open or closed state. $\mathrm{A} \mathrm{Na}_{\mathrm{V}} \mathrm{Sp1}$-specific $\mathrm{S4}-\mathrm{S} 5_{\mathrm{L}}$ peptide, containing the residues supposed to interact with $\mathrm{S6}_{\mathrm{T}}$ according to the $\mathrm{Na}_{\mathrm{v}} \mathrm{Ms}$ structure, induced both an increase in $\mathrm{Na}_{\mathrm{v}} \mathrm{Sp} 1$ current density and a negative shift in the activation curve, consistent with $\mathrm{S}_{4}-\mathrm{S}_{\mathrm{L}}$ stabilizing the open state. Using this approach on a human $\mathrm{Na}_{\mathrm{V}}$ channel, $\mathrm{hNa} \mathrm{v}_{\mathrm{v}} 1.4$, and testing $12 \mathrm{hNa} \mathrm{V}_{\mathrm{v}} 1.4 \mathrm{~S} 4-\mathrm{S} 5_{\mathrm{L}}$ peptides, we identified four activating S4-S5 $\mathrm{L}_{\mathrm{L}}$ peptides. These results suggest that, in eukaryotic $\mathrm{Na}_{V}$ channels, the S4-S5 $L_{L}$ of DI, DII and DIII domains allosterically modulate the activation gate and stabilize its open state.
\end{abstract}

Voltage-gated sodium channels $\left(\mathrm{Na}_{\mathrm{V}}\right)$ are crucial in excitable as well as non-excitable cells and mutations in $\mathrm{Na}_{\mathrm{V}} 1$.x-subunits have been associated with muscular, neuronal and cardiac channelopathies in human ${ }^{1}$. Voltage-gated potassium $\left(\mathrm{K}_{\mathrm{V}}\right)$ channels and prokaryotic $\mathrm{Na}_{\mathrm{V}}$ channels are tetramers of subunits containing six transmembrane segments (S1 to S6). Each of the four subunits consists of one voltage-sensor domain (S1 to S4) and a pore domain (S5-S6). The four pore domains tetramerize to form a single pore module, which is regulated by the four voltage sensor domains. The arrangement of eukaryotic $\mathrm{Na}_{\mathrm{V}}$ channels is similar, with one major difference: the channel is made of a single subunit containing four homologous domains, rather than four identical subunits. Each domain in eukaryotic $\mathrm{Na}_{\mathrm{V}}$ channels is structurally equivalent to one subunit in $\mathrm{K}_{\mathrm{V}}$ or prokaryotic $\mathrm{Na}_{\mathrm{V}}$ channels, and consists of six transmembrane segments (S1 to S6).

Despite intensive work on the voltage-gating of $\mathrm{K}_{\mathrm{V}}$ and $\mathrm{Na}_{\mathrm{V}}$ channels, we still lack a clear picture describing the coupling between S4 voltage-sensor movement and S6 pore gating. Both structural and functional studies identified the linker between S4 and S5 (named S4-S5 ${ }_{\mathrm{L}}$ ) and the C-terminus of S6 (named $\mathrm{S} 6_{\mathrm{T}}$ ), as major actors in this coupling ${ }^{2-21}$. Different coupling mechanisms have been suggested. The crystal structure of $\mathrm{K}_{\mathrm{V}} 1.2$, and more recently the cryo-electron microscopy and crystal structures of both eukaryotic and prokaryotic $\mathrm{Na}_{\mathrm{V}}$ channels suggested that the four $\mathrm{S} 4-\mathrm{S} 5_{\mathrm{L}}$ form a mechanical lever or a constriction ring intimately interacting with $\mathrm{S}_{\mathrm{T}}$ when

${ }^{1}$ Université de Nantes, CNRS, INSERM, I'institut du thorax, F-44000, Nantes, France. ${ }^{2}$ Present address: Buck Institute for Research on Aging, 8001 Redwood Blvd, Novato, California, 94945, USA. ${ }^{3}$ Present address: Cardiovascular Research Institute, University of California, San Francisco, California, 941158-9001, USA. "Present address: Department of Cardiology, Shanghai Ruijin Hospital, Shanghai Jiao Tong University School of Medicine, Shanghai, China. ${ }^{5}$ Cardiovascular Research Institute, University of California, San Francisco, California, 941158-9001, USA. ${ }^{6}$ These authors contributed equally: Olfat A. Malak and Fayal Abderemane-Ali. *email: gildas.loussouarn@inserm.fr 
the activation gate is closed. Upon membrane depolarization, constriction is relieved, and channel activation gate can open ${ }^{10,12,15,19-21}$. On the other hand, other studies performed on the bacterial $\mathrm{Na}_{\mathrm{V}} \mathrm{Ms}$ (from Magnetococcus marinus) channel suggest that the $S 4-S 5_{L}$ may also be involved in an interaction motif stabilizing the channel open state $\mathrm{e}^{8,16,17}$. So rather than only playing the role of a constriction ring (obligatory role, as described for Shaker ${ }^{22}$ ), S4-S5 $\mathrm{L}$ may also allosterically modulate channel gating: the "up" or activated S4 conformation would favor but not impose the channel open state. Such allosteric regulation has been suggested for several channels, including $\mathrm{hK}_{\mathrm{V}} 11.1$ (hERG) and $\mathrm{hK} \mathrm{V}_{\mathrm{V}} 7.1$ (KCNQ1) channels ${ }^{23,24}$. In these channels, we elucidated the nature of this allosteric coupling: when $\mathrm{S} 4$ sensors are in the "down" or deactivated conformation, the four $\mathrm{S} 4-\mathrm{S} 5_{\mathrm{L}}$ bind to $\mathrm{S} 6_{\mathrm{T}}$ in the closed state, stabilizing this state ${ }^{25,26}$. Noteworthy, ATP has also been shown to stabilize the closed state of $\mathrm{K}_{\text {ATP }}$ channels ${ }^{27,28}$. In $\mathrm{K}_{\mathrm{V}}$ channels, $\mathrm{S} 4-\mathrm{S} 5_{\mathrm{L}}$ can thus be seen as an inhibitor (like ATP) attached to the S4 voltage sensor. When the membrane is depolarized, $S 4$ pulls $S 4-S 5_{L}$ out of its binding pocket, leading to channel opening. This is consistent with the observation that specific $S 4-S 5_{L}$-mimicking peptides inhibit $h K_{V} 7.1$ and $h K_{V} 11.1$ channels, by replacing the endogenous segment in the binding pocket ${ }^{25,26}$. This mechanism was recently extended to $\mathrm{hK}_{\mathrm{V}} 10.2$ channels ${ }^{29}$.

In the case of $\mathrm{Na}_{\mathrm{V}}$ channels, such an allosteric model of the voltage-dependent gating mechanism has never been functionally tested. From the interaction motif observed in $\mathrm{Na}_{\mathrm{V}} \mathrm{Ms}$ channel ${ }^{8,16,17}$, we hypothesized that S4-S5 $5_{\mathrm{L}}$ acts as a ligand binding to $\mathrm{S6}_{\mathrm{T}}$ and stabilizing the channel open-state and not the closed state. We used the same peptide approach previously used for $\mathrm{hK}_{\mathrm{V}} 7.1, \mathrm{hK}_{\mathrm{V}} 11.1$ and $\mathrm{hK} \mathrm{V}_{\mathrm{V}} 10.2$ channels $^{25,26,29}$ to test whether $\mathrm{S} 4-\mathrm{S} 5_{\mathrm{L}}$ peptides lead to a gain of function in both prokaryotic and eukaryotic $\mathrm{Na}_{\mathrm{V}}$ channels.

We designed three $\mathrm{S} 4-\mathrm{S}_{\mathrm{L}}$ mimicking peptides specific for prokaryotic $\mathrm{Na}_{\mathrm{V}} \mathrm{Sp} 1$ (from Silicibacter pomeroyi), and three $S 4-S 5_{L}$ mimicking peptides specific for each of the four domains of $h \mathrm{ha}_{\mathrm{V}} 1.4$. None of these $\mathrm{S} 4-\mathrm{S} 5_{\mathrm{L}} \mathrm{pep}-$ tides had an inhibitory effect. One $\mathrm{S} 4-\mathrm{S} 5_{\mathrm{L}}$ peptide from $\mathrm{Na}_{V} \mathrm{Sp} 1$ and at least one $\mathrm{S} 4-\mathrm{S} 5_{\mathrm{L}}$ peptide from DI, DII and DIII domains of $\mathrm{hNa}_{\mathrm{V}} 1.4$ promoted channel activity. Our results suggest that, as demonstrated in three $\mathrm{K}_{\mathrm{V}}$ channels, the ligand/receptor model of interaction between $\mathrm{S} 4-\mathrm{S} 5_{\mathrm{L}}$ and $\mathrm{S}_{\mathrm{T}}$ applies also to both $\mathrm{Na}_{\mathrm{V}} \mathrm{Sp} 1$ and $\mathrm{hNa} \mathrm{V}_{\mathrm{V}} 1.4$ channels, with one major difference: $\mathrm{S} 4-\mathrm{S} 5_{\mathrm{L}}$ stabilizes the open state in $\mathrm{Na}_{\mathrm{V}}$ channels.

\section{Results}

A specific S4-S5 $5_{\mathrm{L}}$ mimicking peptide activates the bacterial channel $\mathrm{Na}_{\mathrm{V}} \mathrm{Sp} 1$. First, we tested the ligand/receptor model on $\mathrm{Na}_{\mathrm{V}} \mathrm{Sp} 1$, a bacterial channel that is organized as a tetramer of identical subunits. If endogenous $\mathrm{S} 4-\mathrm{S}_{\mathrm{L}}$ acts like a ligand that stabilizes the activation gate in the open state, then a peptide mimicking endogenous $\mathrm{S} 4-\mathrm{S}_{\mathrm{L}}$ should increase $\mathrm{Na}_{\mathrm{V}} \mathrm{Sp} 1$ channel activity (Fig. 1A). Three peptides were designed. One peptide, $\mathrm{S} 4-\mathrm{S} 5_{\mathrm{L}}(-3)$, is aligned with the active peptides for $h K_{\mathrm{V}} 7.1^{25}$ and $h K_{\mathrm{V}} 11.1^{26}$ channel (Fig. 1B). Noteworthy, this peptide includes the sequence that aligns with $\mathrm{Na}_{V} \mathrm{Ms}$ RRVVQ motif. This RRVVQ motif engages a series of salt bridge and hydrogen-bonded interactions with $S 6_{\mathrm{T}}$ and $\mathrm{S} 3$, such interactions playing a major role in channel open state stabilization ${ }^{16}$. Two other $\mathrm{Na}_{\mathrm{V}} \mathrm{Sp} 1$ peptides, $\mathrm{S} 4-\mathrm{S} 5_{\mathrm{L}}(0)$ and $\mathrm{S} 4-\mathrm{S} 5_{\mathrm{L}}(+3)$ lack this sequence. Each $\mathrm{Na}_{\mathrm{V}} \mathrm{Sp} 1$ peptide, $S 4-S 5_{L}(-3), S 4-S 5_{L}(0)$ or $S 4-S 5_{L}(+3)$, was functionally tested separately. One peptide-encoding plasmid was co-transfected with the $\mathrm{Na}_{\mathrm{V}} \mathrm{Sp}$ 1-encoding plasmid. Results were compared to those from reference cells, co-transfected with $\mathrm{Na}_{\mathrm{V}} \mathrm{Sp} 1$ and an unrelated peptide (hK $\mathrm{V}_{\mathrm{V}} 11.1 \mathrm{~S} 6 \mathrm{C}$-terminal part, I663-T675, Control 1). An additional negative control, also unrelated to $\mathrm{Na}_{\mathrm{V}}$ channels $\left(\mathrm{hK} \mathrm{V}_{\mathrm{V}} 11.1 \mathrm{~S} 4-\mathrm{S} 5_{\mathrm{L}}\right.$, A536-F551, Control 2) was used to confirm the absence of the Control 1 peptide effect. In all the following experiments, Control 2 did not show any significant difference, when compared to Control 1.

When co-expressed with $\mathrm{Na}_{\mathrm{V}} \mathrm{Sp}$ 1, the $\mathrm{S} 4-\mathrm{S}_{\mathrm{L}}(-3)$ peptide provoked a gain of function on the current density (Fig. 2, Supplemental Table 1). Moreover, the activation curve was shifted to more negative potential with no concurrent shift of the voltage-dependence of the activation/inactivation kinetics. This latter observation excludes a membrane charge screening, locally changing the potential detected by the voltage-sensor (Supplemental Fig. 1). It is possible that enhancement of the $\mathrm{Na}_{\mathrm{V}} \mathrm{Sp} 1$ current density of $\mathrm{Na}_{\mathrm{V}} \mathrm{Sp} 1$ at $30 \mathrm{mV}$ stimuli is partially caused by the negative shift of voltage dependent activation. Since a gain of function may also lead to incomplete channel deactivation $^{25}$, we also tested if the current measured at $-90 \mathrm{mV}$, in the presence of $\mathrm{S} 4-\mathrm{S} 5_{\mathrm{L}}$ peptides, was greater than in ctrl1 and ctrl 2 conditions. Our data shows that this is not the case (Supplemental Fig. 2), suggesting that channel deactivation is complete in the presence of peptides. The other two peptides, $\mathrm{S} 4-\mathrm{S} 5_{\mathrm{L}}(0)$ and $\mathrm{S} 4-\mathrm{S} 5_{\mathrm{L}}(+3)$ lacking the sequence aligning to the $\mathrm{Na}_{\mathrm{V}} \mathrm{Ms}$ RRVVQ motif had no effect. The gain of function, caused by $\mathrm{Na}_{\mathrm{V}} \mathrm{Sp} 1$ $S 4-S 5_{L}(-3)$ peptide suggests that $\mathrm{Na}_{\mathrm{V}} \mathrm{Sp} 1$ follows a ligand/receptor model of voltage-dependent gating, with $\mathrm{S} 4-\mathrm{S} 5_{\mathrm{L}}$ stabilizing the channel in the open state.

Because the active peptide $\mathrm{S} 4-\mathrm{S}_{\mathrm{L}}(-3)$ contains two arginines (R116 and R117) that are absent in the inactive peptides $\left(S 4-S 5_{L}(0)\right.$ and $S 4-S 5_{L}(+3)$ ), we tested the role of these positively charged residues in $\mathrm{Na}_{\mathrm{V}} \mathrm{Sp} 1$ gating. Charged amino-acid distribution in $S 4-S 5_{L}$ and $S 6_{T}$ is quite different between $\mathrm{Na}_{\mathrm{V}} \mathrm{Sp} 1$ and $\mathrm{Na}_{\mathrm{V}} \mathrm{Ms}$, with an additional arginine at the start of $\mathrm{Na}_{\mathrm{V}} \mathrm{Sp} 1 \mathrm{~S} 4-\mathrm{S} 5_{\mathrm{L}}$ (R114, before R116 and R117, cf. black arrows pointing to $\mathrm{R}$ in Supplemental Fig. 3) and an additional aspartate at position 222 in $S 6_{\mathrm{T}}$ (black arrow pointing to D in Supplemental Fig. 3). In order to test the potential contribution of R114, R116 and R117 to the stabilization of the open state, we mutated one by one each arginine to an aspartate carrying the opposite charge. R114D did not have any effect on channel activity (Fig. 3A-B,E), but both R116D and R117D led to nonfunctional channels (Fig. 3A,C-D), consistent with a major role of both arginines in $\mathrm{Na}_{\mathrm{V}} \mathrm{Sp} 1$ open state stabilization by both the endogenous and exogenous peptides. But because of the absence of detectable current, we could not exclude that $\mathrm{R} 116 \mathrm{D}$ and R117D were preventing channel trafficking to the membrane. In order to confirm electrostatic interaction between $\mathrm{S} 4-\mathrm{S}_{\mathrm{L}}$ and $\mathrm{S} 6_{\mathrm{T}}$ to stabilize $\mathrm{Na}_{\mathrm{V}} \mathrm{Sp} 1$ open state, we had to identify residues in $\mathrm{S}_{\mathrm{T}}$ with which R116 and/or R117 interacts. D222 was, among other residues, a good candidate because it is in a region that aligns with $\mathrm{Na}_{V} \mathrm{Ms}$ residues interacting with $\mathrm{S} 4-\mathrm{S}_{\mathrm{L}}$ to stabilize the channel open state (Supplemental Fig. 3 ). Interestingly, the addition of the D222R mutation on top of the nonfunctional R116D mutant was not only able to restore channel activity but also led to a channel that is more prone to be open, as compared to when both amino acids at position 
A

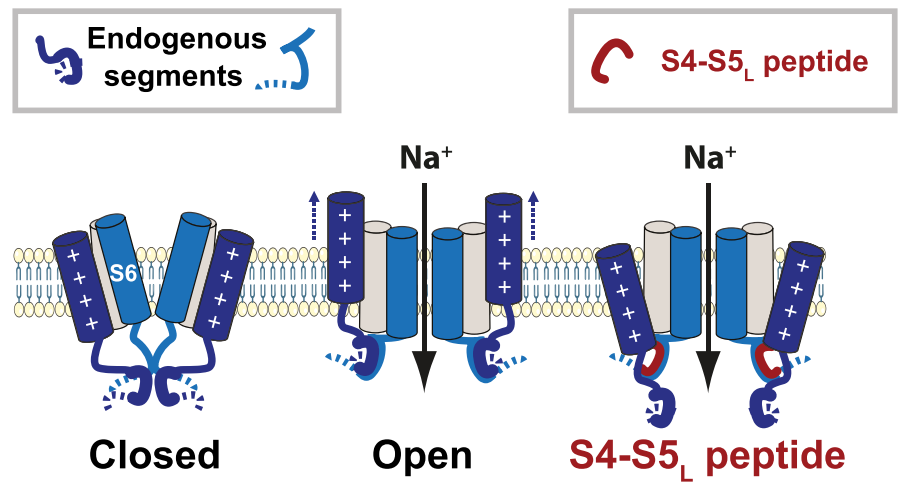

B

$$
\begin{array}{r}
\text { S4-S5 } 5_{L}(+3) \mathrm{Na}_{v} 1.4 \\
\text { S4-S5 }(0) \mathrm{Na}_{v} 1.4 \\
\text { S4-S5 } 5_{L}(-3) \mathrm{Na}_{v} 1.4
\end{array}
$$

$\mathrm{hNa}_{\mathrm{v}} 1.4 \mathrm{DI}$ : LTEFVDLGNISALRTERVLRALKTITVIPGLKTIVGALIQSVKKLSDVMILTVFCLSVFALVGLQLFMGNLR $\mathrm{hNa}_{\mathrm{v}} 1.4 \mathrm{DII}$ : ELGLANVQGLSVLRSERLIRVFKLARSWPTINMLIRIIGNSVGALGNLTLVLAIIVFIFAVVGMQLFGEKSYK $\mathrm{hNa}_{\mathrm{v}} 1.4$ DIII : WLGYSELGPIKSLRTLRALRPLRALSRFEGMRVV̄VNALLGAIPS IMNVLLVCLIFWLIFSIMGVNLFAGKFY

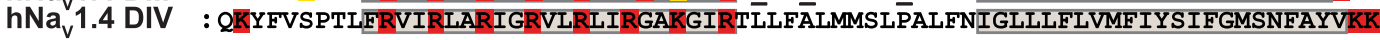
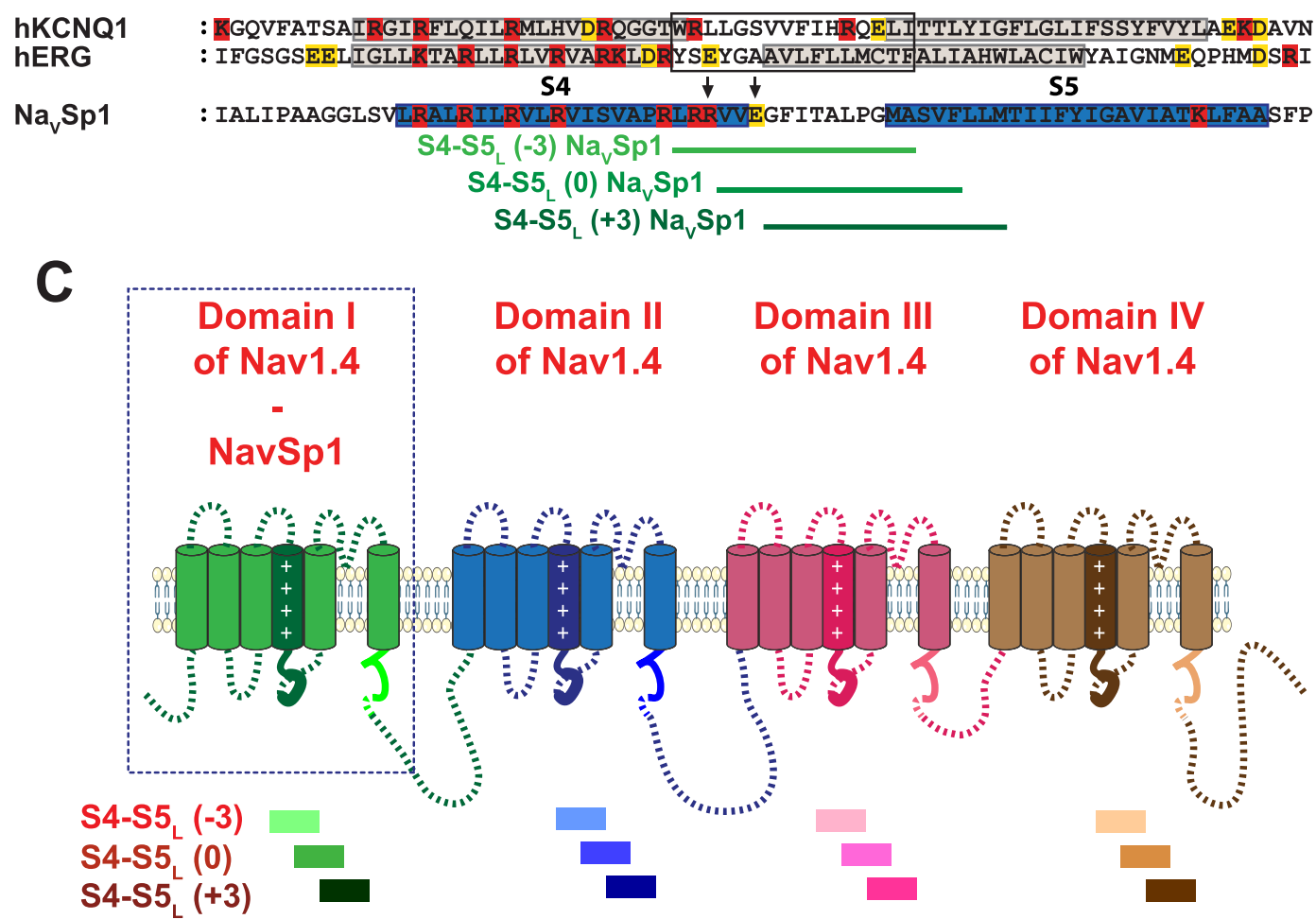

Figure 1. Ligand/receptor model. Multiple alignment used to design $\mathrm{Na}_{\mathrm{V}} \mathrm{Sp} 1$ and $\mathrm{Na}_{\mathrm{V}} 1.4 \mathrm{~S} 4-\mathrm{S} 5_{\mathrm{L}}$ peptides. (A) scheme of the ligand/receptor model in which $\mathrm{S} 4-\mathrm{S5}_{\mathrm{L}}$ (endogenous segment, deep blue) binds to $\mathrm{S6}_{\mathrm{T}}$ (endogenous segment, light blue) to stabilize the channel in the open state, as suggested by works on $\mathrm{Na}_{\mathrm{V}} \mathrm{Ms}$ channel. The $\mathrm{S} 4-\mathrm{S}_{\mathrm{L}}$ peptide (red) mimics endogenous $\mathrm{S} 4-\mathrm{S}_{\mathrm{L}}$, stabilizing the channel open conformation. (B) Multiple alignment used to design $\mathrm{Na}_{\mathrm{V}} \mathrm{Sp} 1$ and $\mathrm{hNa}_{\mathrm{V}} 1.4$ peptides from previously potent $\mathrm{hK} \mathrm{V}_{\mathrm{V}} 7.1$ and $\mathrm{hK}_{\mathrm{V}} 11.1$ S4-S5 ${ }_{\mathrm{L}}$ peptides (framed). Starting from $\mathrm{S} 4-\mathrm{S}_{\mathrm{L}}(-3)$ peptide, two others peptides were designed, by shifting toward the C-terminus by $3\left(S 4-S_{\mathrm{L}}(0)\right)$ and 6 amino acids $\left(S 4-\mathrm{S}_{\mathrm{L}}(+3)\right)$. Red: basic residues, yellow: acidic residues. Colored boxes represent the S4 and S5 segments. Mutated residues in skeletal channelopathies are underlined (in $\mathrm{Na}_{\mathrm{V}} 1.4 \mathrm{~S} 4-\mathrm{S}_{\mathrm{L}}$ ). Arrows point to $\mathrm{Na}_{\mathrm{V}} \mathrm{Ms}$-corresponding residues interacting with $\mathrm{S6}_{\mathrm{T}}$ (text) $\mathrm{C}$ : Scheme of the $\mathrm{hNa}_{\mathrm{V}} 1.4$ and $\mathrm{Na}_{\mathrm{V}} \mathrm{Sp} 1$ channels showing the color used for each peptide/domain.

116 and 222 carry a positive charge (D222R): we observed an increase in current amplitude and a -20 - $\mathrm{mV}$ shift in the activation curve (Fig. 4). Such activity restoration and gain of function when amino acids at position 116 and 222 carry opposite charges $(\mathrm{R} 116 \mathrm{D}+\mathrm{D} 222 \mathrm{R})$ suggest that both endogenous and exogenous $\mathrm{S} 4-\mathrm{S} 5_{\mathrm{L}}$ peptides stabilize the channel open state through specific $\mathrm{S} 4-\mathrm{S} 5_{\mathrm{L}}$ and $\mathrm{S} 6_{\mathrm{T}}$ interaction. 

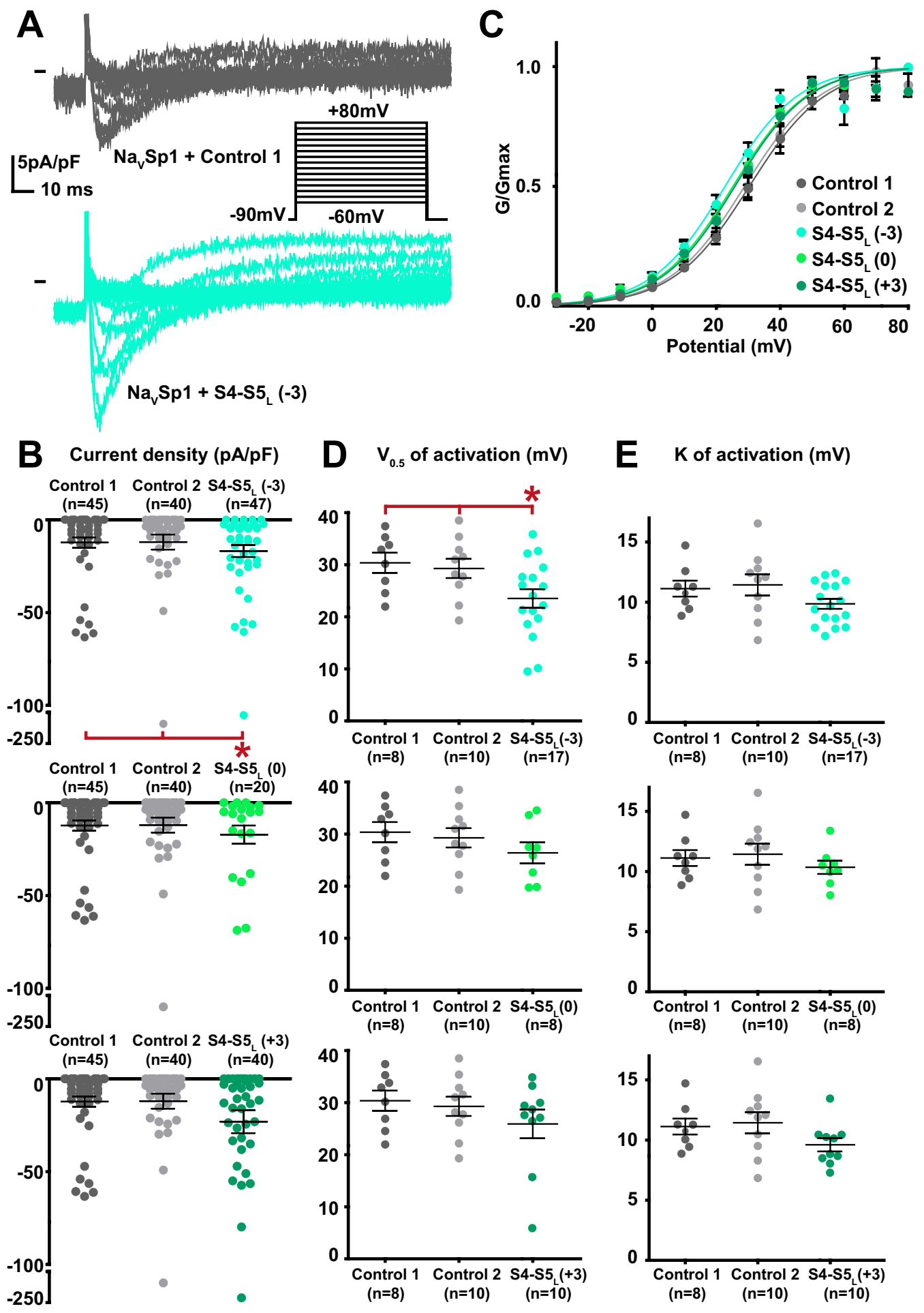

Figure 2. Effect of $\mathrm{Na}_{\mathrm{V}} \mathrm{Sp} 1 \mathrm{~S} 4-\mathrm{S} 5_{\mathrm{L}}$ mimicking peptides on $\mathrm{Na}_{\mathrm{V}} \mathrm{Sp} 1$ current density and activation curve. (A) representative, superimposed current recordings in COS-7 cells transfected with $\mathrm{Na}_{\mathrm{V}} \mathrm{Sp} 1$ and control 1 (top trace) or $\mathrm{S} 4-\mathrm{S}_{\mathrm{L}}(-3)$ peptide (bottom trace). Inset: activation voltage protocol used (holding potential: $-90 \mathrm{mV}$; 300 -ms pulse at the indicated potentials; one sweep every $5 \mathrm{~s}$ ). (B) Dot plot and mean \pm sem of peak $\mathrm{Na}_{\mathrm{V}} \mathrm{Sp} 1$ current densities recorded in COS-7 cells co-transfected with $\mathrm{Na}_{\mathrm{V}} \mathrm{Sp} 1$ and the indicated peptide, at $30 \mathrm{mV}$. (C) Relative peak conductance versus membrane potential curves for $\mathrm{Na}_{\mathrm{V}} \mathrm{Sp} 1$ channels in COS-7 cells co-transfected with $\mathrm{Na}_{\mathrm{V}} \mathrm{Sp} 1$ and the indicated peptide. Lines are Boltzmann fits to the data. (D,E) Dot plot and mean \pm sem of $\mathrm{Na}_{\mathrm{V}} \mathrm{Sp} 1$ half-activation potential $\left(\mathrm{V}_{0.5} ; \mathbf{D}\right)$ and activation slope $(\mathrm{K} ; \mathbf{E})$ in COS-7 cells co-transfected with $\mathrm{Na}_{\mathrm{V}} \mathrm{Sp} 1$ and the indicated peptide. *p value $v s$. both controls $<0.05$. 
A
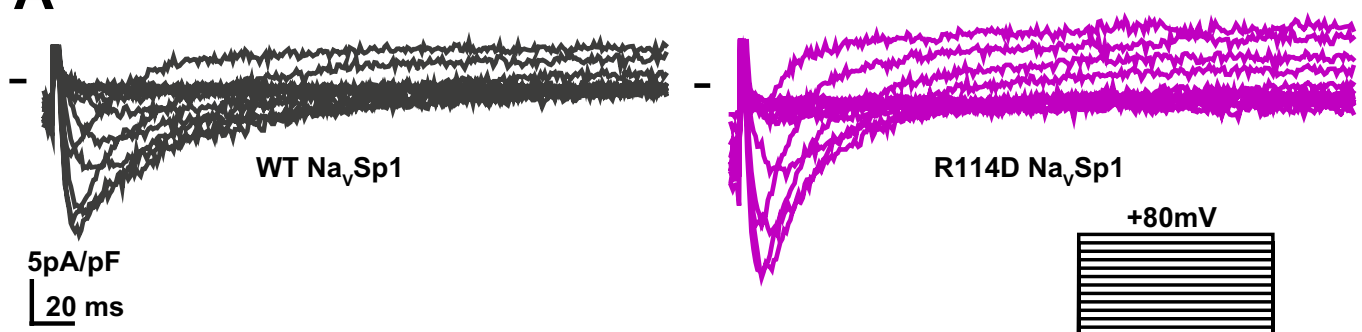

R114D Na $\mathrm{Sp} 1$

$+80 \mathrm{mV}$

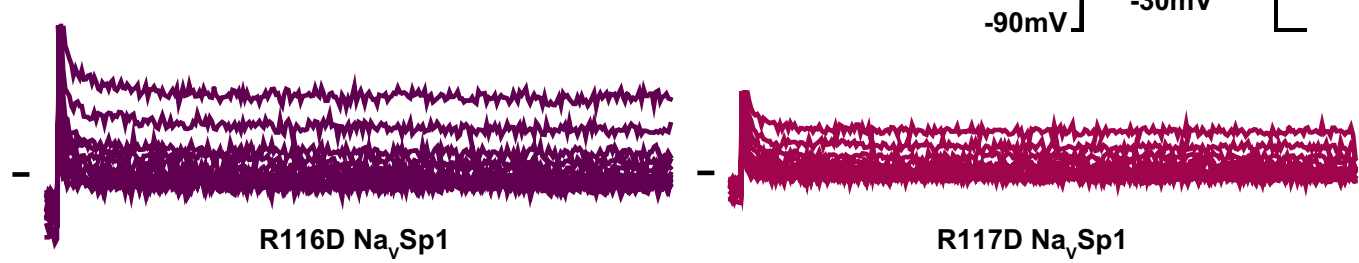

B
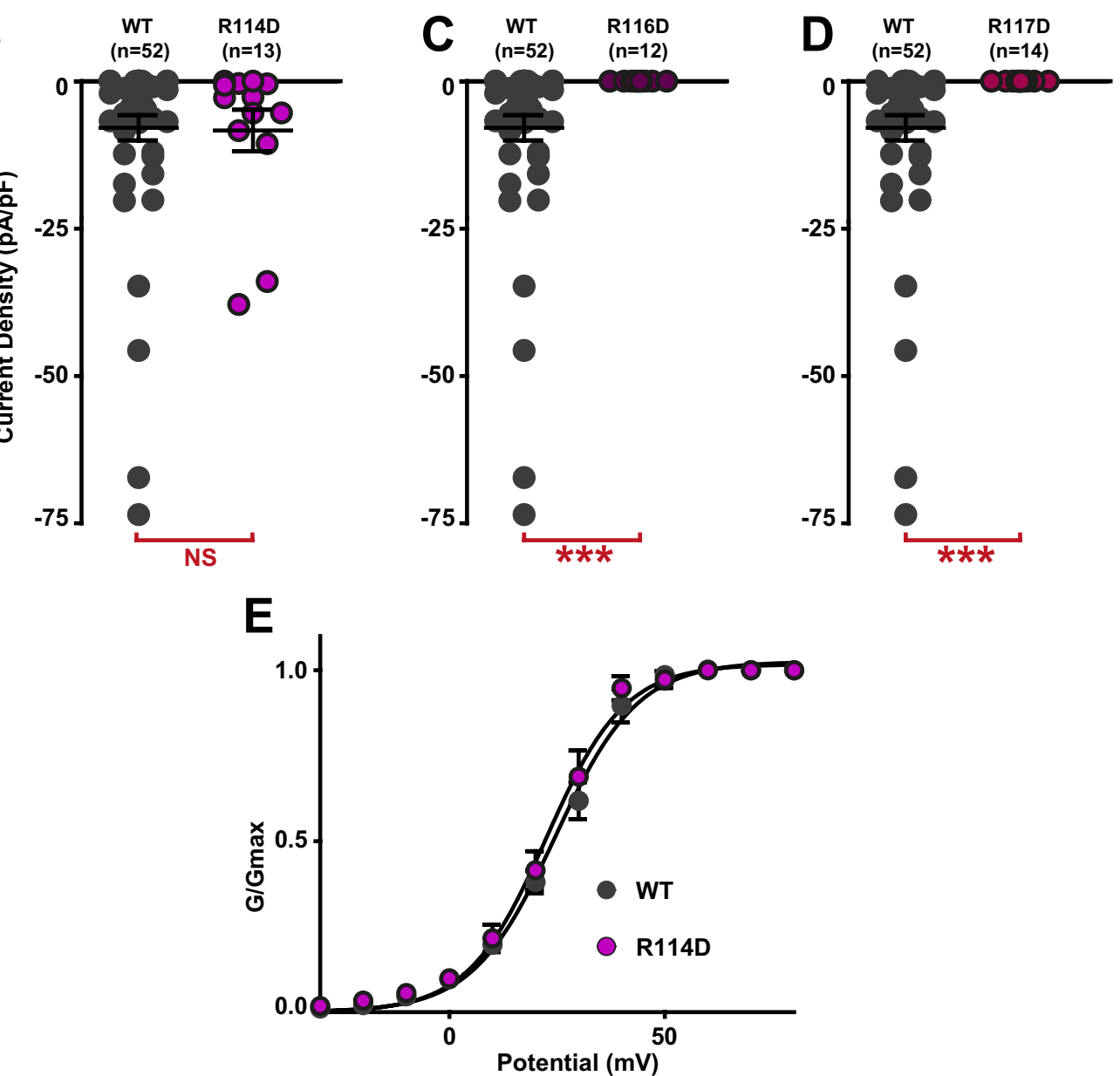

Figure 3. Effect of charge reversal in amino acids present in $\mathrm{Na}_{V} S p 1 S 4-\mathrm{S}_{\mathrm{L}}(-3)$ activating peptide on $\mathrm{Na}_{\mathrm{V}} \mathrm{Sp} 1$ current density and activation curve. (A) representative, superimposed recordings of WT and mutant $\mathrm{Na}_{\mathrm{V}} \mathrm{Sp} 1$ current. Activation voltage protocol used is the same as in Fig. 2. (B-D) Dot plot and mean \pm sem of peak current densities recorded in COS-7 cells transfected with WT or mutant $\mathrm{Na}_{\mathrm{V}} \mathrm{Sp} 1$, at $30 \mathrm{mV}$. (E) Relative peak conductance versus membrane potential curves for WT or mutant $\mathrm{Na}_{\mathrm{V}} \mathrm{Sp} 1$ channels transfected in COS-7. Lines are Boltzmann fits to the data. $* * *$ p value $v s$. WT $<0.001$.

$\mathrm{hNa} \mathrm{V}_{\mathrm{V}}$ 1.4 S4-S5 $\mathrm{L}$ peptides activate $\mathrm{hNa} \mathrm{V}_{\mathrm{V}}$ 1.4. We also tested the ligand/receptor model on the $\mathrm{hNa}_{\mathrm{V}} 1.4$ voltage-gated channel that is organized as a single subunit of four homologous domains ${ }^{11,15,20,21}$. Again, three $\mathrm{S} 4-\mathrm{S} 5_{\mathrm{L}}$-encoding plasmids were designed for each domain, based on sequence alignment with $\mathrm{hK} \mathrm{V}_{\mathrm{V}} 7.1$ 
A
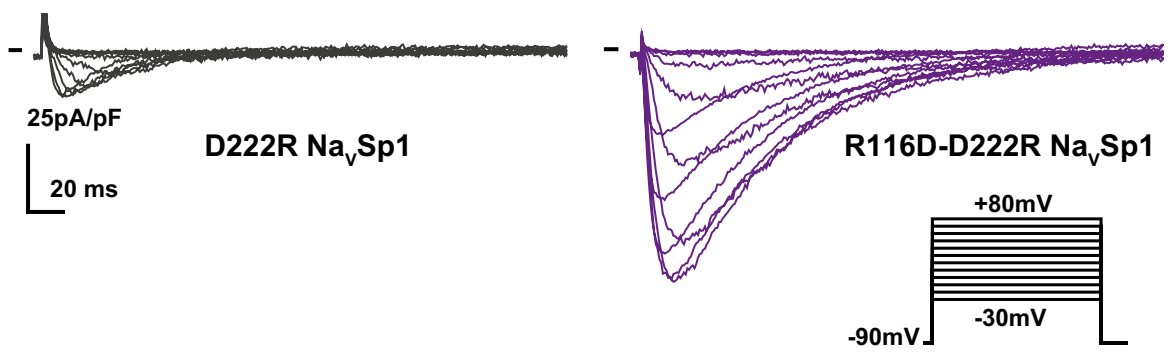

B

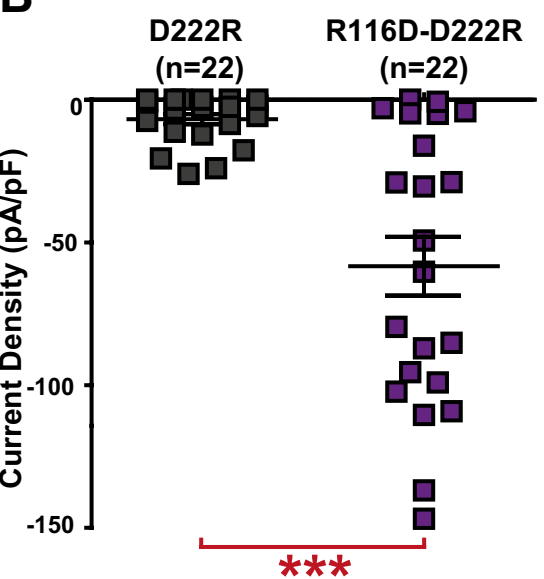

C
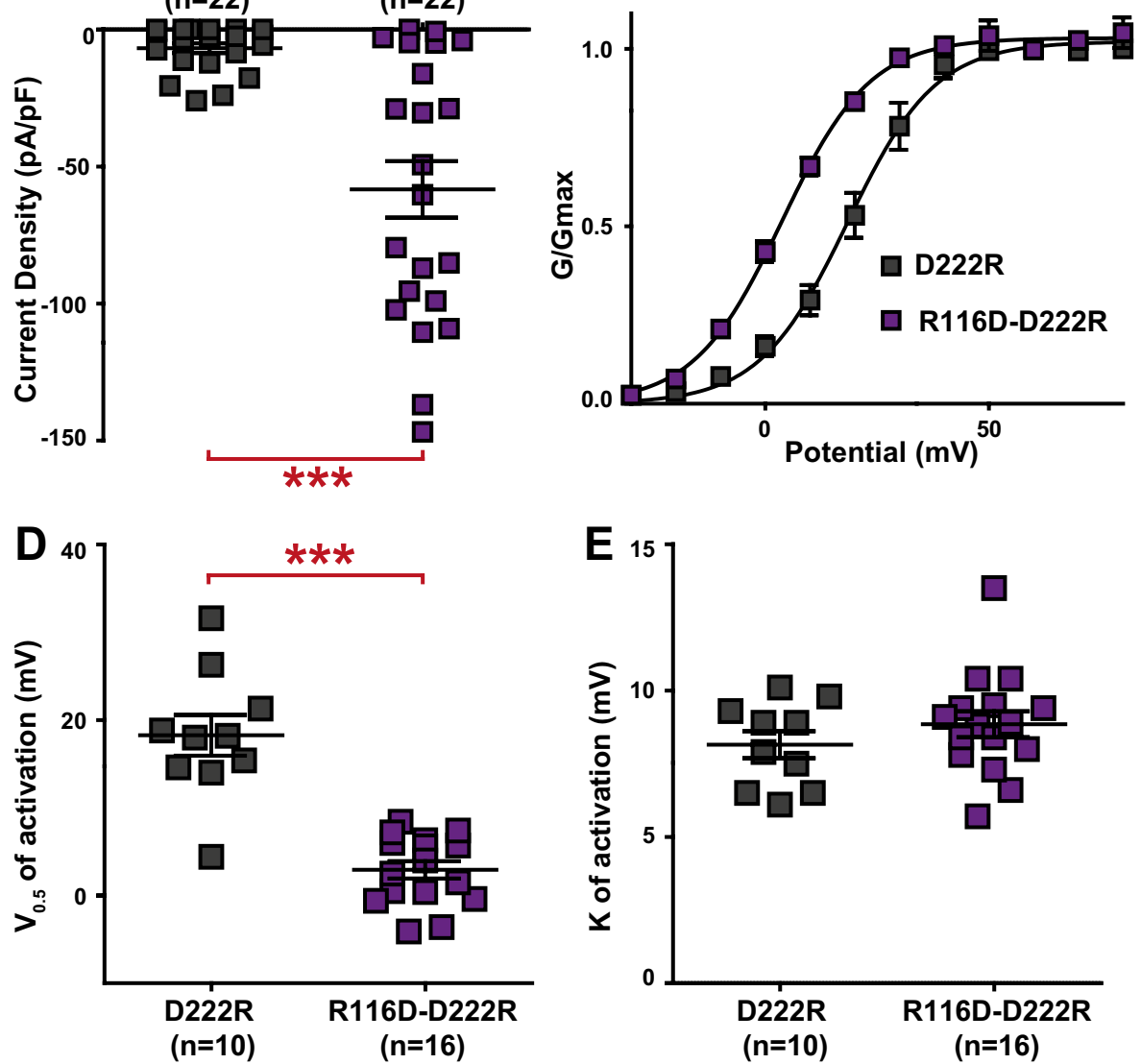

Figure 4. Opposite charges at position $116\left(\mathrm{Na}_{\mathrm{V}} \mathrm{Sp} 1 \mathrm{~S} 4-\mathrm{S} 5_{\mathrm{L}}\right)$ and $222\left(\mathrm{Na}_{\mathrm{V}} \mathrm{Sp} 1 \mathrm{~S} 6_{\mathrm{T}}\right)$ stabilizes the $\mathrm{Na}_{\mathrm{V}} \mathrm{Sp} 1$ channel open state. (A) representative, superimposed current recordings of single $\mathrm{Na}_{\mathrm{V}} \mathrm{Sp} 1$ mutant $\mathrm{D} 222 \mathrm{R}$ and double mutant D222R/R116D. Activation voltage protocol used is the same as in Fig. 2. (B) Dot plot and mean \pm sem of peak current densities recorded in COS-7 cells transfected with D222R or D222R/R116D Na $S p 1$, at $30 \mathrm{mV}$. (C) Relative peak conductance versus membrane potential curves for D222R or D222R/R116D Na $\mathrm{Sp} 1$ channels transfected in COS-7 cells. Lines are Boltzmann fits to the data. (D,E) Dot plot and mean \pm sem of $\mathrm{Na}_{\mathrm{V}} \mathrm{Sp} 1$ half-activation potential $\left(\mathrm{V}_{0.5} ; \mathrm{D}\right)$ and activation slope $(\mathrm{K} ; \mathrm{E})$ in COS-7 cells transfected with D222R or $\mathrm{D} 222 \mathrm{R} / \mathrm{R} 116 \mathrm{D} \mathrm{Na} \mathrm{V}_{\mathrm{V}} \mathrm{Sp} 1$. ***p value $v s . \mathrm{D} 222 \mathrm{R}<0.001$.

and $\mathrm{hK}_{\mathrm{V}} 11.1$ (Fig. 1B). Each of the 12 designed S4-S5 $5_{\mathrm{L}}$ peptides was tested separately: each $\mathrm{hNa} \mathrm{V}_{\mathrm{V}} 1.4 \mathrm{~S} 4-\mathrm{S} 5_{\mathrm{L}}$ peptide-encoding plasmid was co-transfected with $\mathrm{hNa}_{\mathrm{V}} 1.4$ and $\mathrm{hNa}_{\mathrm{V}} \beta 1$-encoding plasmids.

Among the 12 tested $\mathrm{hNa}_{\mathrm{V}} 1.4 \mathrm{~S} 4-\mathrm{S} 5_{\mathrm{L}}$ peptides, three peptides increased the $\mathrm{hNa} \mathrm{V}_{\mathrm{V}} 1.4$ current density. These activating peptides mimic three of the four $\mathrm{hNa} \mathrm{V}_{\mathrm{V}} 1.4 \mathrm{~S} 4-\mathrm{S} 5$ linkers, in domain I $\left(\mathrm{S} 4-\mathrm{S} 5_{\mathrm{L}}(+3)\right)$, domain II $\left(\mathrm{S} 4-\mathrm{S}_{\mathrm{L}}(+3)\right)$ and domain III $\left(\mathrm{S} 4-\mathrm{S5}_{\mathrm{L}}(0)\right)$ of $\mathrm{hNa} \mathrm{V}_{\mathrm{V}} 1.4$ (Figs. 5B-8B, Supplemental Table 2).

One additional peptide in domain III shifted the activation curve to more negative potentials $\left(\mathrm{S} 4-\mathrm{S}_{\mathrm{L}}(-3)\right.$, Supplemental Table 2; Fig. 7C-E), also leading to a gain of function. This $\mathrm{S} 4-\mathrm{S} 5_{\mathrm{L}}(-3)$ peptide is different from the $S 4-S 5_{L}(0)$ peptide that increased the current density in the same domain: it is shifted by three amino acids toward the N-terminus. We did not observe any alteration of the activation/inactivation kinetics by any of the peptides (Supplemental Fig. 4). 


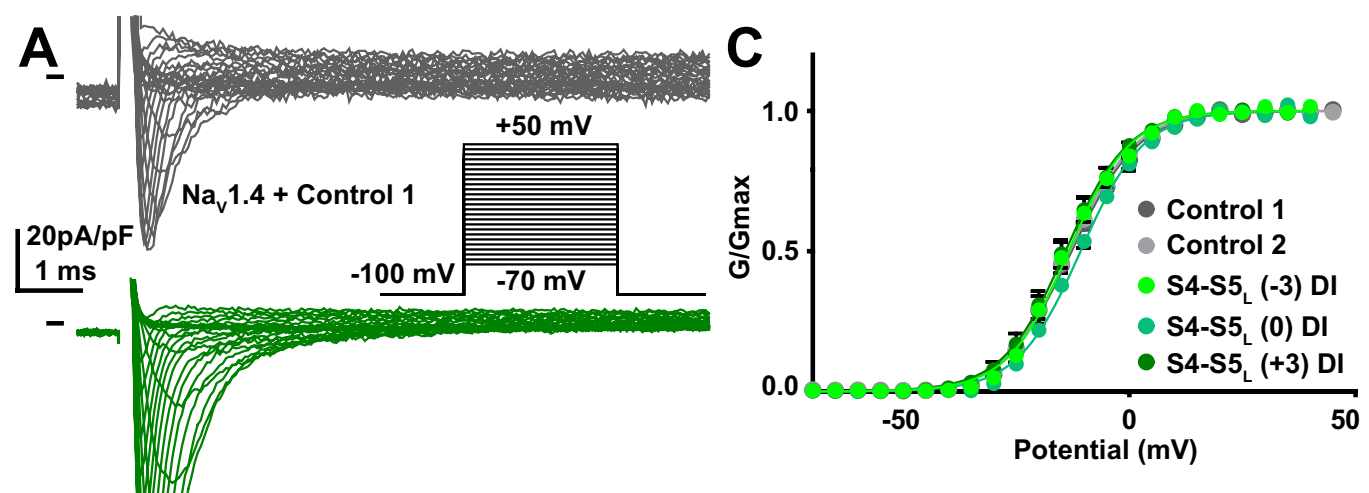

$\mathrm{Na}_{\mathrm{v}} 1.4+\mathrm{S} 4-\mathrm{S5} 5_{\mathrm{L}}(+3) \mathrm{DI}$

B Current density $(\mathrm{pA} / \mathrm{pF})$

Control 1 Control 2 S4-S5 $(-3)$

$(n=119) \quad(n=110) \quad$ DI $(n=18)$

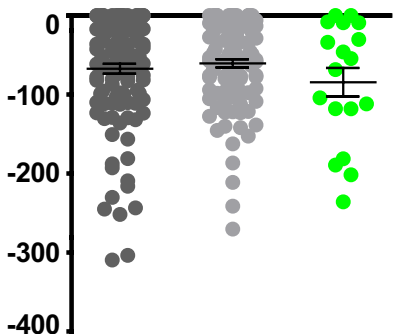

Control 1 Control 2 S4-S5 $(0)$ $(n=119) \quad(n=110) \quad D I(n=24)$
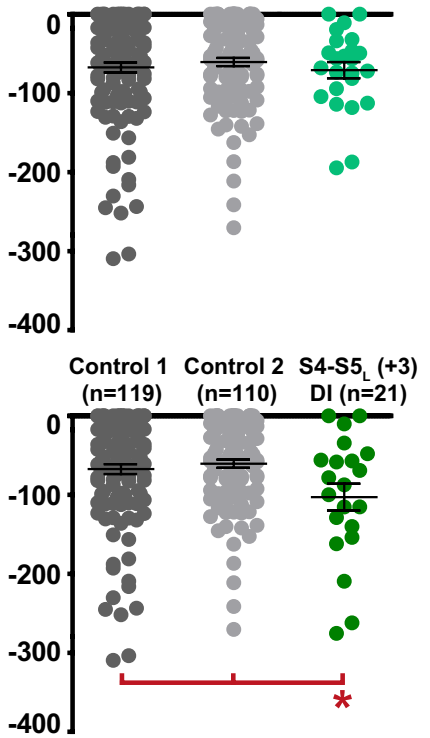

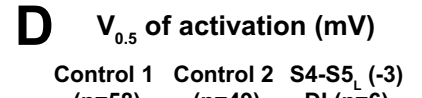

$(\mathrm{n}=58) \quad(\mathrm{n}=49) \quad$ DI $(\mathrm{n}=6)$

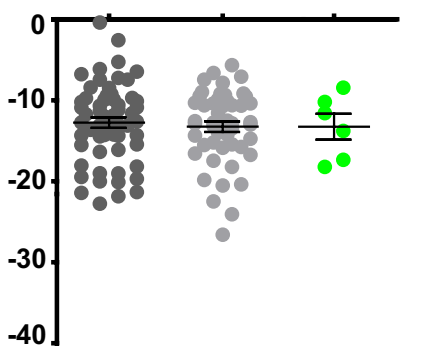

Control 1 Control 2 S4-S5 $(0)$ $(n=58) \quad(n=49) \quad D I(n=12)$
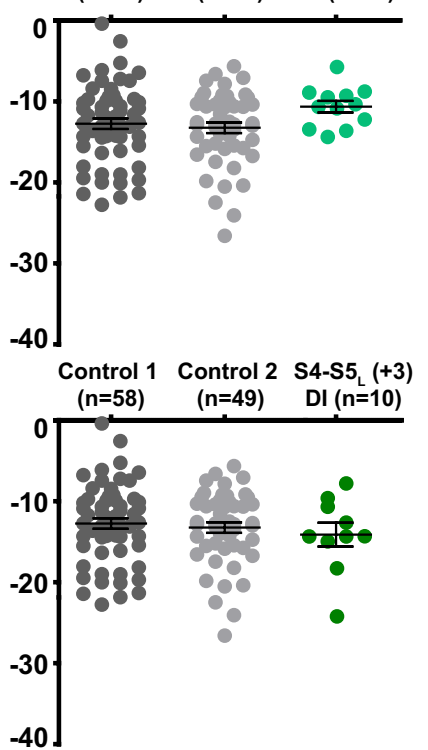
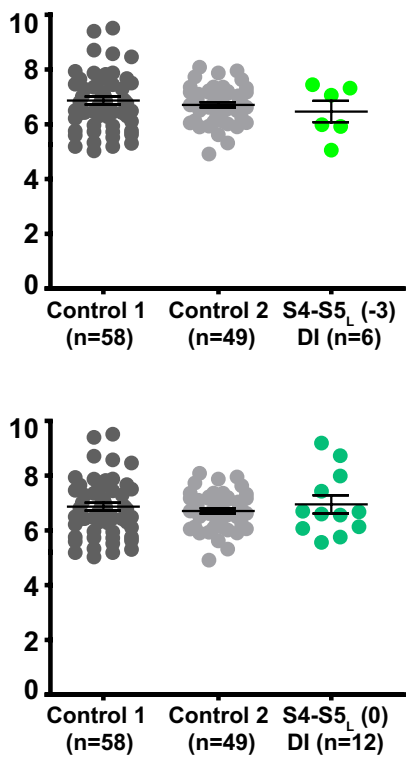

E $\mathrm{K}$ of activation $(\mathrm{mV})$

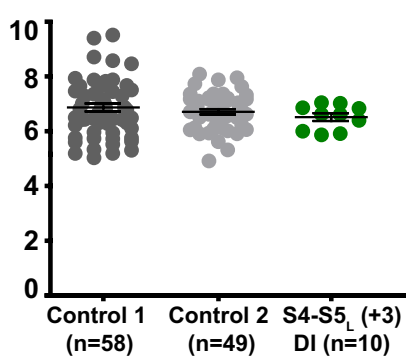

Figure 5. Effect of $\mathrm{Na}_{\mathrm{V}} 1.4 \mathrm{~S} 4-\mathrm{S} 5_{\mathrm{L}}$ mimicking peptides of domain $\mathrm{I}$ on $\mathrm{Na}_{\mathrm{V}} 1.4$ current density and activation curve. (A) representative, superimposed current recordings in COS-7 cells co-transfected with $\mathrm{Na}_{V} 1.4, \mathrm{Na}_{\mathrm{V}} ß 1$, and control 1 (top trace) or domain I S4-S5 $5_{L}(+3)$ peptide (bottom trace). Inset: activation voltage protocol used (holding potential: $-100 \mathrm{mV}$; 30-ms pulse; one sweep every $2 \mathrm{~s}$ ). (B) Dot plot and mean \pm sem of peak $\mathrm{Na}_{\mathrm{V}} 1.4$ current densities recorded in COS-7 cells co-transfected with $\mathrm{Na}_{\mathrm{V}} 1.4, \mathrm{Na} \mathrm{V}_{\mathrm{V}} \mathrm{B}$, and the indicated peptide, at $0 \mathrm{mV}$. C: Relative peak conductance versus membrane potential curves for $\mathrm{Na}_{\mathrm{V}} 1.4$ channels in the same cell groups as in (B). Lines are Boltzmann fits to the data. (D,E) Dot plot and mean \pm sem of $\mathrm{Na}_{\mathrm{V}} 1.4$ half-activation potential $\left(\mathrm{V}_{0.5} ; \mathrm{D}\right)$ and activation slope $(\mathrm{K} ; \mathrm{E})$ in the same cells group as in $(\mathbf{B})$. * p value $v$ s. both controls $<0.05$. 


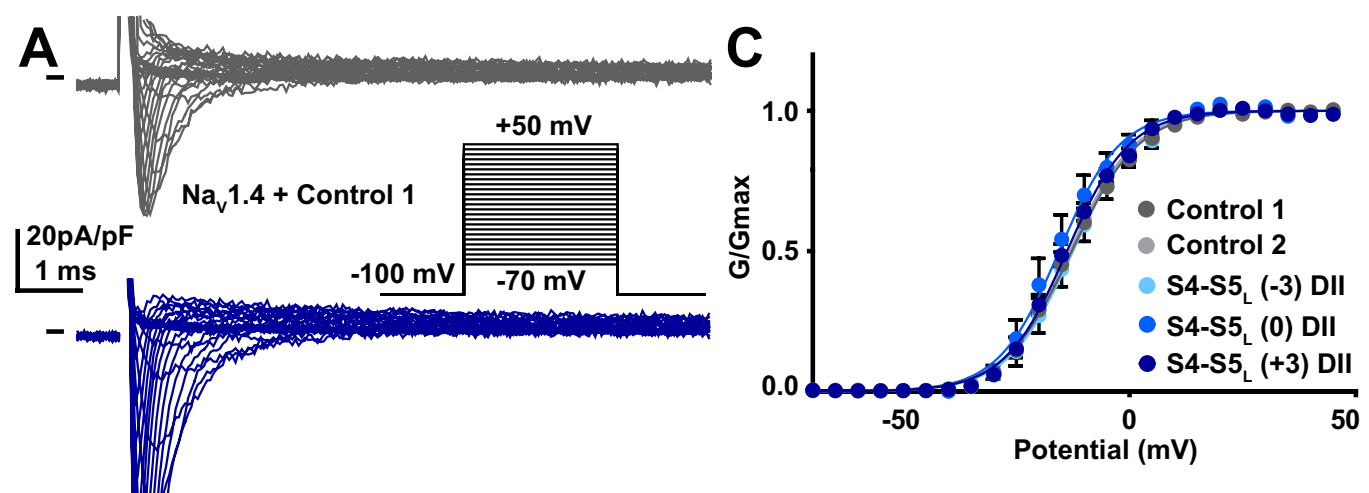

$\mathrm{Na}_{\mathrm{v}} 1.4+\mathrm{S} 4-\mathrm{S5} 5_{\mathrm{L}}(+3)$ DII
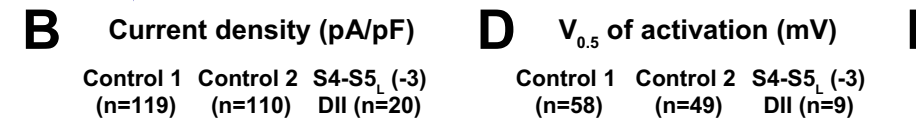

E $K$ of activation (mV)
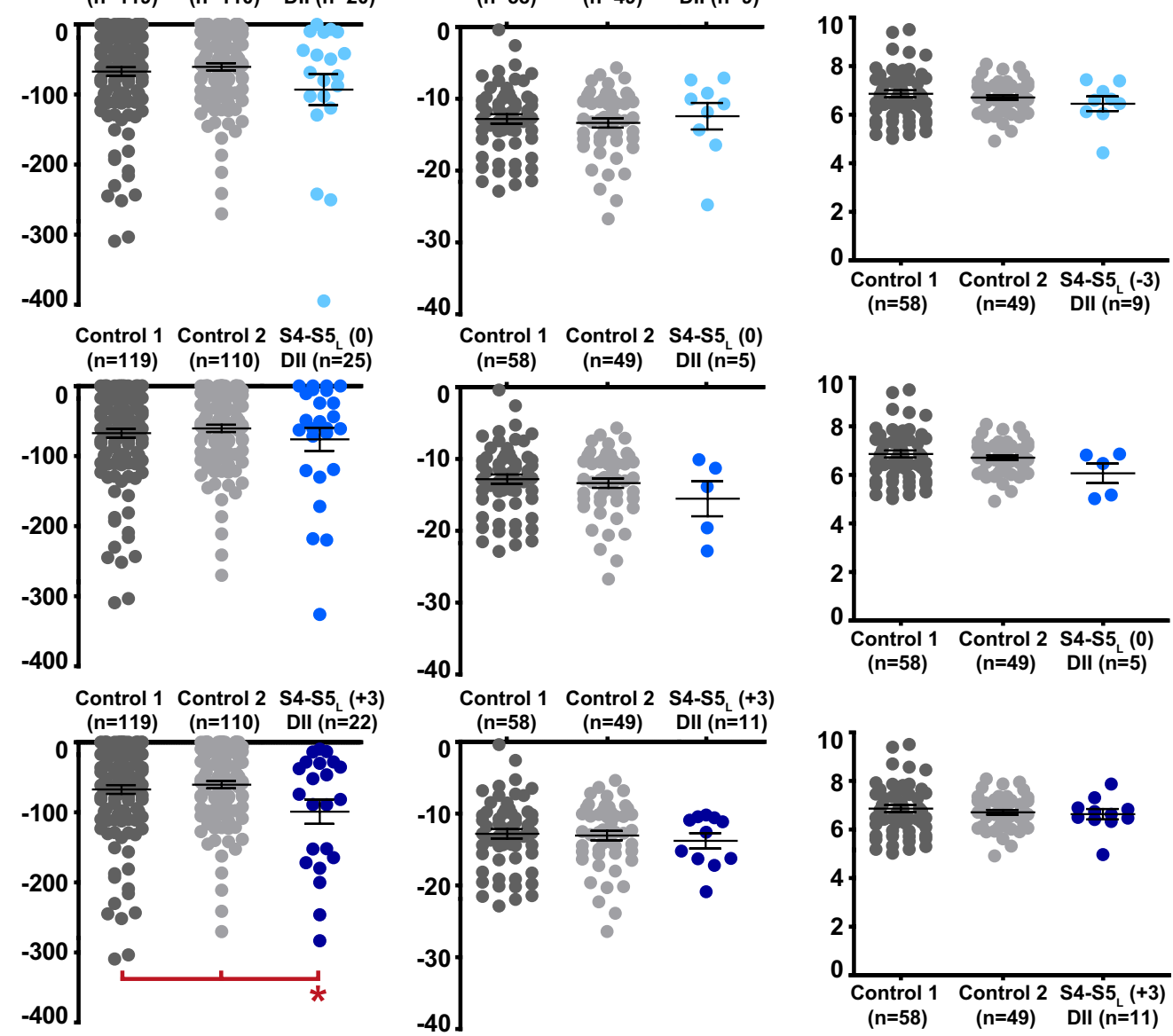

Figure 6. Effect of $\mathrm{Na}_{\mathrm{V}} 1.4 \mathrm{~S} 4-\mathrm{S} 5_{\mathrm{L}}$ mimicking peptides of domain II on $\mathrm{Na}_{\mathrm{V}} 1.4$ current density and activation curve. (A) representative, superimposed current recordings in COS-7 cells co-transfected with $\mathrm{Na}_{V} 1.4, \mathrm{Na}_{\mathrm{V}} ß 1$, and control 1 (top trace) or domain II S4-S5 $5_{\mathrm{L}}(+3)$ peptide (bottom trace). Inset: activation voltage protocol used (holding potential: $-100 \mathrm{mV}$; 30-ms pulse; one sweep every $2 \mathrm{~s}$ ). (B) Dot plot and mean \pm sem of peak $\mathrm{Na}_{\mathrm{V}} 1.4$ current densities recorded in COS-7 cells co-transfected with $\mathrm{Na}_{\mathrm{V}} 1.4, \mathrm{Na}_{\mathrm{V}} ß 1$, and the indicated peptide, at $0 \mathrm{mV}$. (C) Relative peak conductance versus membrane potential curves for $\mathrm{Na}_{\mathrm{V}} 1.4$ channels in the same cell groups as in (B). Lines are Boltzmann fits to the data. (D,E) Dot plot and mean \pm sem of $\mathrm{Na}_{\mathrm{V}} 1.4$ half-activation potential $\left(\mathrm{V}_{0.5} ; \mathrm{D}\right)$ and activation slope $(\mathrm{K} ; \mathrm{E})$ in the same cells group as in $(\mathbf{B})$. * p value $v$ s. both controls $<0.05$. 


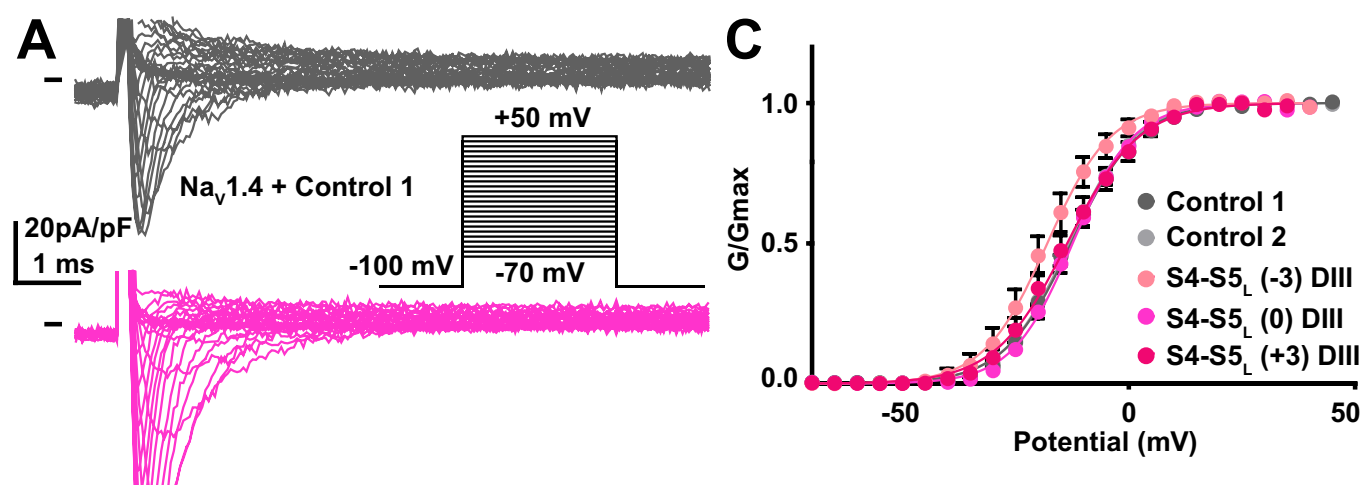

$\mathrm{Na}_{\mathrm{v}} 1.4+\mathrm{S} 4-\mathrm{S5} 5_{\mathrm{L}}(0)$ DIII
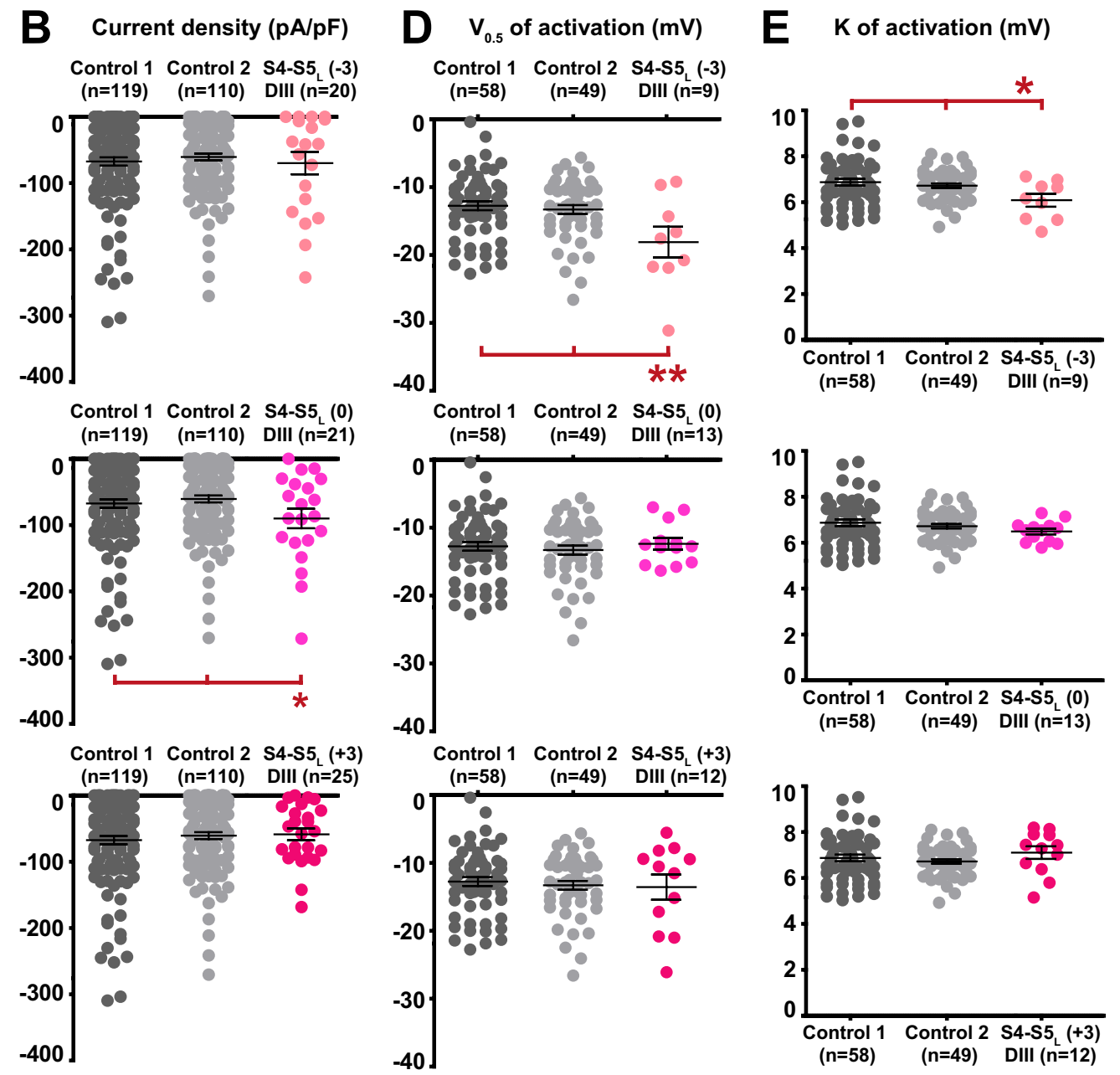

Figure 7. Effect of $\mathrm{Na}_{\mathrm{V}} 1.4 \mathrm{~S} 4-\mathrm{S} 5_{\mathrm{L}}$ mimicking peptides of domain III on $\mathrm{Na}_{\mathrm{V}} 1.4$ current density and activation curve. (A) representative, superimposed current recordings in COS-7 cells co-transfected with $\mathrm{Na}_{V} 1.4, \mathrm{Na}_{V} ß 1$, and control 1 (top trace) or domain III S4-S5 $5_{L}(0)$ peptide (bottom trace). Inset: activation voltage protocol used (holding potential: $-100 \mathrm{mV} ; 30$-ms pulse; one sweep every $2 \mathrm{~s}$ ). (B) Dot plot and mean \pm sem of peak $\mathrm{Na}_{\mathrm{V}} 1.4$ current densities recorded in COS-7 cells co-transfected with $\mathrm{Na}_{\mathrm{V}} 1.4, \mathrm{Na} \mathrm{V}_{\mathrm{V}} \mathrm{l}$, and the indicated peptide, at $0 \mathrm{mV}$. C: Relative peak conductance versus membrane potential curves for $\mathrm{Na}_{\mathrm{V}} 1.4$ channels in the same cell groups as in (B). Lines are Boltzmann fits to the data. (D,E) Dot plot and mean \pm sem of $\mathrm{Na}_{\mathrm{V}} 1.4$ half-activation potential $\left(\mathrm{V}_{0.5} ; \mathbf{D}\right)$ and activation slope $(\mathrm{K} ; \mathbf{E})$ in the same cells group as in $(\mathbf{B}) . *$ p value $v$ s. both controls $<0.05$. **p value $v s$. both controls $<0.01$. 

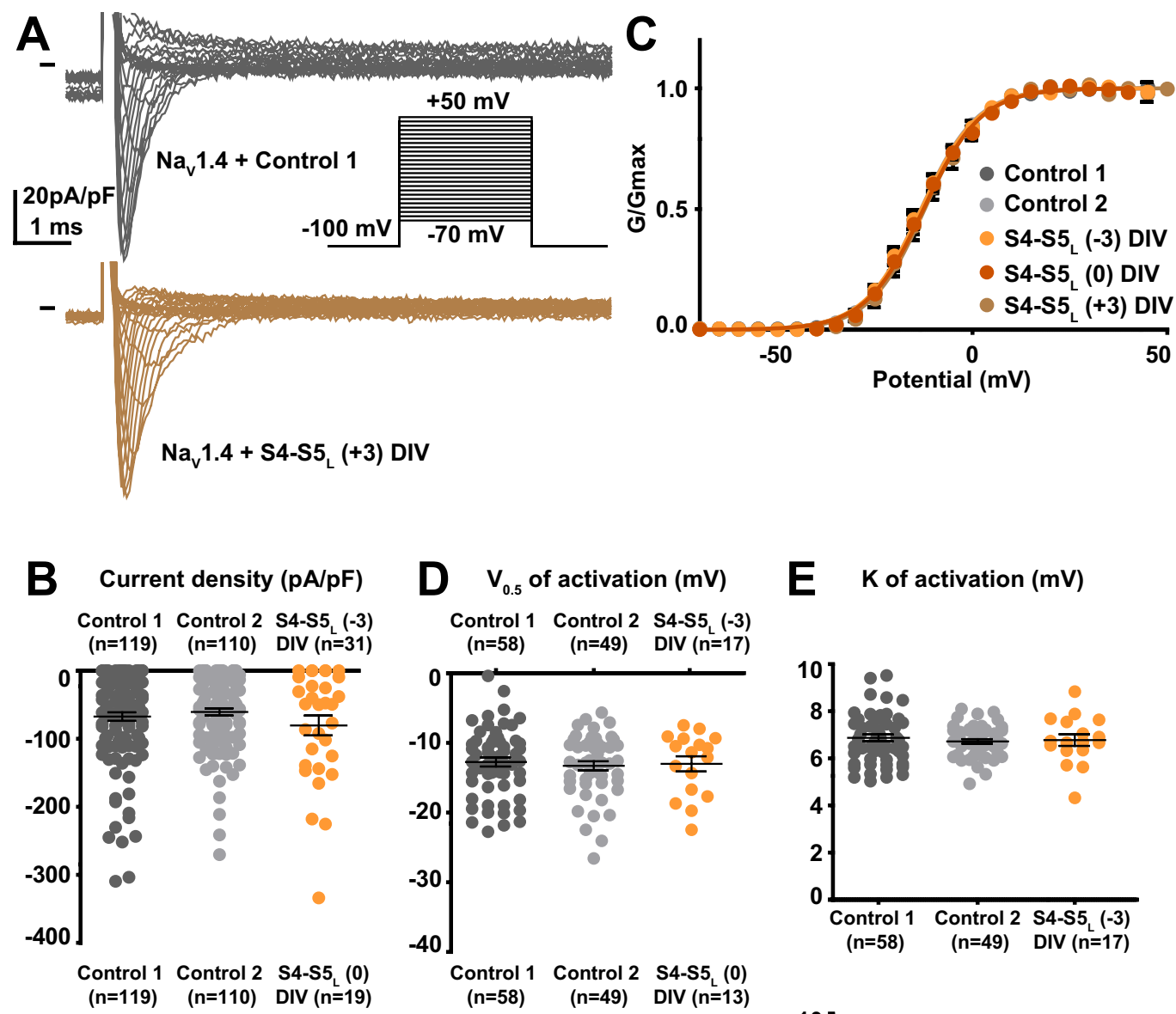

\section{E K of activation (mV)}
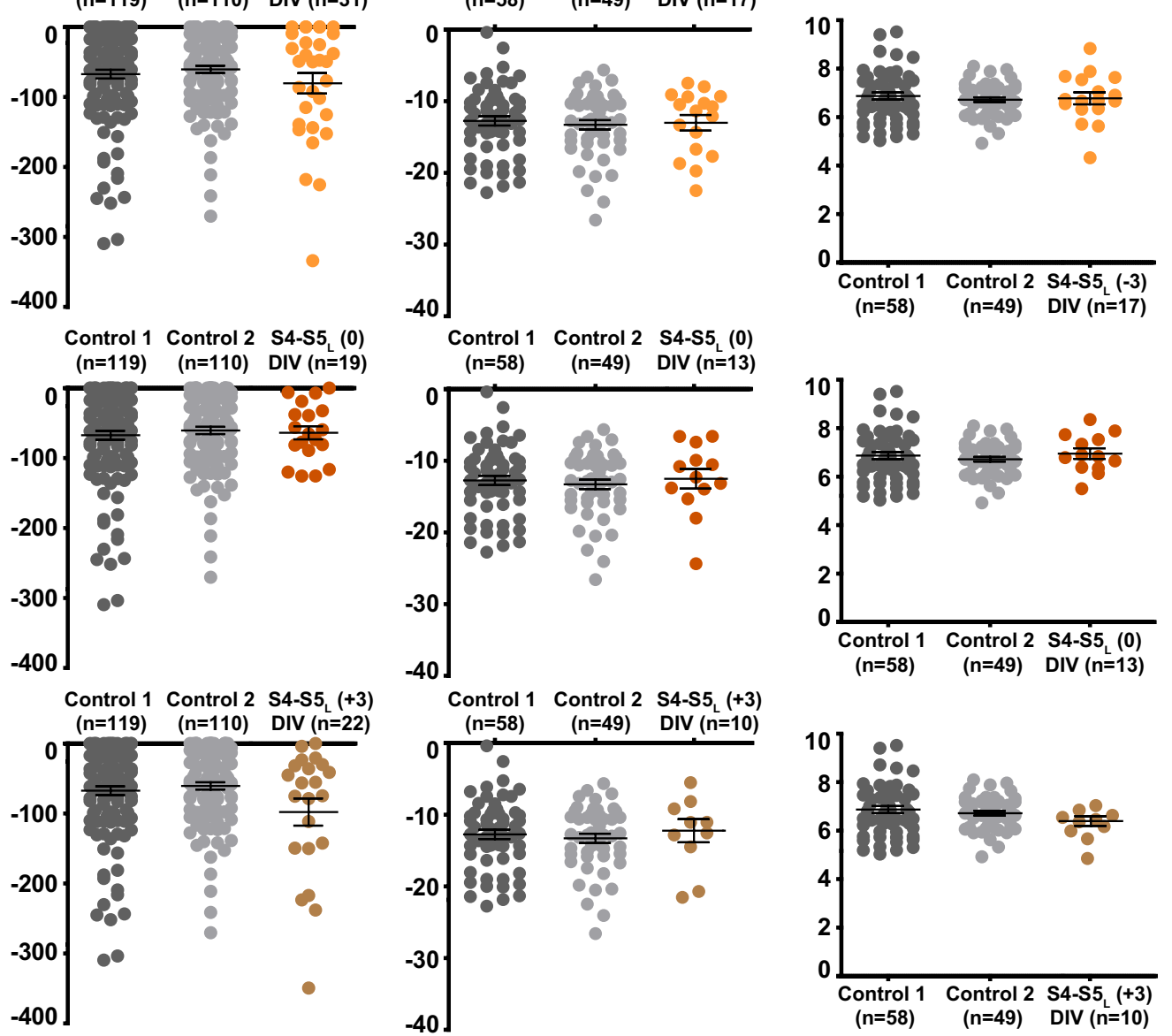

Figure 8. Effect of $\mathrm{Na}_{\mathrm{V}} 1.4 \mathrm{~S} 4-\mathrm{S} 5_{\mathrm{L}}$ mimicking peptides of domain $\mathrm{IV}$ on $\mathrm{Na}_{\mathrm{V}} 1.4$ current density and activation curve. (A) representative, superimposed current recordings in COS-7 cells co-transfected with $\mathrm{Na}_{V} 1.4, \mathrm{Na}_{V} ß 1$, and control 1 (top trace) or domain IV S4-S5 $\left.\mathrm{L}_{\mathrm{L}}+3\right)$ peptide (bottom trace). Inset: activation voltage protocol used (holding potential: $-100 \mathrm{mV}$; 30-ms pulse; one sweep every $2 \mathrm{~s}$ ). (B) Dot plot and mean \pm sem of peak $\mathrm{Na}_{\mathrm{V}} 1.4$ current densities recorded in COS-7 cells co-transfected with $\mathrm{Na}_{\mathrm{V}} 1.4, \mathrm{Na}_{\mathrm{V}} ß 1$, and the indicated peptide, at $0 \mathrm{mV}$. (C) Relative peak conductance versus membrane potential curves for $\mathrm{Na}_{\mathrm{V}} 1.4$ channels in the same cell groups as in (B). Lines are Boltzmann fits to the data. (D,E) Dot plot and mean \pm sem of $\mathrm{Na}_{\mathrm{V}} 1.4$ half-activation potential $\left(\mathrm{V}_{0.5} ; \mathbf{D}\right)$ and activation slope $(\mathrm{K} ; \mathbf{E})$ in the same cells group as in $(\mathbf{B})$. 
S4-S5 $L_{\mathrm{L}}$ peptides do not modify $\mathrm{hNa} 1.4$ channel trafficking. Cell surface biotinylation experiments were performed in order to verify whether increased current densities were due to gating alteration or to an increased channel trafficking. These experiments were done using the three peptides in domain I, II, III of $h \mathrm{ha}_{\mathrm{V}} 1.4$ that were causing an increase in current density, and using the $\mathrm{S} 4-\mathrm{S}_{\mathrm{L}}(+3)$ peptide in domain IV of $\mathrm{hNa}_{\mathrm{V}} 1.4$ that was showing a trend of increased current density, although not significant. Neither the total nor the biotinylated fraction (plasma membrane) of $\mathrm{hNa}_{\mathrm{V}} 1.4$ protein was increased by any of the peptides, suggesting that domain I S4-S5 $5_{\mathrm{L}}(+3)$, domain II S4-S5 $\mathrm{L}(+3)$ and domain III S4-S5 $5_{\mathrm{L}}(0)$ peptides increase $\mathrm{hNa} \mathrm{V}_{\mathrm{V}} 1.4$ current density through an alteration of channel gating and not its trafficking (Fig. 9; Supplemental Fig. 5).

Thus, out of the 12 tested peptides, four led to a gain of function of $\mathrm{hNa}_{\mathrm{V}} 1.4$ channel through an effect on channel gating.

Effects of combination of peptides. Since in $\mathrm{hNa}_{\mathrm{V}} 1.4$ the S4-S5 linker sequences of the four domains differ, we explored if co-transfecting two activating peptides exerts a stronger effect on $\mathrm{hNa}_{\mathrm{V}} 1.4$ current density than the individual peptides, as two domains will be stabilized open instead of only one. In order to keep the same expression level of the channel, we needed to keep the same total DNA quantity in all conditions. Thus, to combine two peptides we added half quantity of each peptide-encoding plasmid, as compared to conditions with only one peptide. We did not observe any increase in current density when DI-S4-S5 $(+3)$ and DII-S4-S5 $5_{\mathrm{L}}(+3)$ peptides were co-expressed. This observation suggests that combination of the two peptides in lesser quantity was not as potent as when only one peptide was expressed (Fig. 10). It is possible that the presence of (i) smaller quantity of peptides in addition to (ii) some steric hindrance prevent the activating effect. Noteworthy, domains I and II are adjacent, consistent with the hypothetical steric hindrance. To limit the effect of steric hindrance, we selected activating peptides from two non-adjacent domains, namely DI-S4-S5 $5_{\mathrm{L}}(+3)$ and DIII-S4-S5 $5_{\mathrm{L}}(0)$. Indeed, co-expression of these DI-S4-S5 $5_{\mathrm{L}}(+3)$ and DIII-S4-S5 $\mathrm{L}_{\mathrm{L}}(0)$ peptides caused an increase in the $\mathrm{hNa} \mathrm{V}_{\mathrm{V}} 1.4$ current density. Such an increase was similar but not greater than when only one peptide was expressed, probably because each of the peptides was present in lesser quantity. This observation highlights a limit of the model in which S4-S5 effects are not strong enough to potentially quantify the synergistic effect of the combination of peptides.

S4-S5 ${ }_{\mathrm{L}}$ peptides modify $\mathrm{hNa} 1.4$ channel inactivation. Since mutations in domains I, III and IV S4-S5 ${ }_{\mathrm{L}}$ have been associated with a large modification of the $\mathrm{Na}_{\mathrm{V}} 1.4$ channel fast inactivation ${ }^{30-32}$, we also tested the effect of the peptides on channel inactivation. We observed an increase in the slope factor of the inactivation curve when DI-S4-S5 $5_{\mathrm{L}}(+3)$ or DIII-S4-S5 $5_{\mathrm{L}}(+3)$ peptide was expressed (Supplemental Figs. 6-9; Supplemental Table 2). Also, and consistent with the effect of the combination of peptides on the activation curve, effect of DI-S4-S5 $5_{L}(+3)$ was still observed when it was co-expressed with the peptide corresponding to the non-adjacent domain (III), but not with the peptide corresponding to the adjacent domain (II) (Supplemental Fig. 10).

\section{Discussion}

In this work, we used a $\mathrm{S} 4-\mathrm{S}_{\mathrm{L}}$ mimicking peptide approach to test whether voltage-gated sodium channels follow the ligand/receptor model previously proposed for $\mathrm{hK}_{\mathrm{V}} 7.1^{25}, \mathrm{hK}_{\mathrm{V}} 11.1^{26}$ and $\mathrm{hK}_{\mathrm{V}} 10.2^{29}$ channels. We identified one activating S4-S5 $5_{\mathrm{L}}$ peptide in $\mathrm{Na}_{\mathrm{V}} \mathrm{Sp} 1$ and four in $\mathrm{hNa}_{\mathrm{V}} 1.4$, suggesting that $\mathrm{Na}_{\mathrm{V}}$ channels follow a ligand/ receptor model of voltage-dependent gating (Fig. 11c): when the membrane is depolarized, endogenous $\mathrm{S} 4-\mathrm{S}_{\mathrm{L}}$ stabilizes the open state of $\mathrm{Na}_{V}$ channels, as indicated by the $\mathrm{Na}_{\mathrm{V}} \mathrm{Ms}$ structure captured in the open state ${ }^{8,16,17}$. This contrasts with what is happening with $\mathrm{K}_{\mathrm{V}}$ channels: when the membrane is polarized, endogenous $\mathrm{S} 4-\mathrm{S} 5_{\mathrm{L}}$ stabilizes the closed state of $K_{\mathrm{V}}$ channels, as suggested by several studies ${ }^{25,26,29}$.

The various peptide effects, either on current density or on the activation voltage dependence, suggest that peptides are acting on different conformational transitions leading to channel opening. Due to the multi-state process of channel voltage-dependent gating, implying several conformational changes, peptides affinity may be high enough for the alteration of one parameter (e.g., current density), but not for the alteration of the other one (e.g., $\mathrm{V}_{0.5}$, slope factor). The peptides effects on current density but not on the activation voltage dependence have already been observed in $\mathrm{hK}_{\mathrm{V}} 11.1$ channel $^{26}$ and $\mathrm{hK}_{\mathrm{V}} 7.1$ channels $\mathrm{s}^{25}$ and were also described in a kinetic model of the peptide effect on $\mathrm{K}_{\mathrm{v}} 10.2$ channels $^{29}$. In $\mathrm{hK}_{\mathrm{V}} 11.1$ channel, we show that a $\mathrm{S}_{\mathrm{T}}$ mimicking peptide has only an effect on the current density when affinity is low but can also drastically change the activation curve when its affinity is increased by a specific disulfide bridge ${ }^{26}$.

Here, all the data obtained on $\mathrm{hNa}_{\mathrm{V}} 1.4$ suggest that $\mathrm{S} 4-\mathrm{S}_{\mathrm{L}}$ in domain I, II and III play a significant role in the channel voltage dependence of activation. In the neuronal channel $\mathrm{Na}_{\mathrm{V}} 1.2$, mutations of $\mathrm{S} 4$ gating charges in all four domains were found to affect the activation ${ }^{33}$. Nevertheless, of the mutations that shifted the $\mathrm{V}_{0.5}$ of activation, the most pronounced effects were observed when the fourth charge in each of domains I, II, and III was neutralized. This suggests that domains I to III play a critical role in coupling the voltage sensor with the activation gate of $\mathrm{Na}_{\mathrm{V}} 1.2$, consistent with our results on $\mathrm{hNa}_{\mathrm{V}} 1.4$. Moreover, voltage-clamp fluorimetry experiments performed on $\mathrm{Na}_{\mathrm{V}} 1.4 \mathrm{~S} 4$ segments showed that domain I, II and III play a significant role in the channel voltage-dependence of activation, also consistent with our results on $\mathrm{hNa}_{\mathrm{V}} 1.4^{34}$.

Although consistent with a ligand/receptor model, $\mathrm{S} 4-\mathrm{SS}_{\mathrm{L}}$ peptides effects on $\mathrm{Na}_{\mathrm{V}} \mathrm{Sp} 1$ and $\mathrm{hNa} \mathrm{V}_{\mathrm{V}} 1.4$ are moderate. It is worth mentioning that these effects are nevertheless in the range of those observed in previous studies on three different voltage-gated potassium channels ${ }^{25,26,29}$. In the previous studies, we interpreted that the $S 4-S 5_{\mathrm{L}} / \mathrm{S}_{\mathrm{T}}$ interaction has to be loose, probably due to the low affinity between native $\mathrm{S} 4-\mathrm{S}_{\mathrm{L}}$ and $\mathrm{S} 6_{\mathrm{T}}$, which is necessary for S4-S5 $5_{\mathrm{L}}$ ligand unbinding and channel opening during membrane depolarization ${ }^{26}$. In the channel, this low affinity is compensated by the imposed proximity of the two segments. Experimentally, this can be compensated only partly by high peptide concentration. In two $\mathrm{K}_{\mathrm{V}}$ channels, we found a way to reinforce $\mathrm{S} 4-\mathrm{S}_{\mathrm{L}}$ peptide binding to $\mathrm{S}_{\mathrm{T}}$ via a specific disulfide bridge between two cysteines, and hence, increase their effects on the channel ${ }^{26,29}$. It would be interesting to identify such a pair of cysteines in $\mathrm{Na}_{\mathrm{V}}$ channels. 



Figure 9. Effect on $\mathrm{Na}_{\mathrm{V}} 1.4$ channel expression of $\mathrm{S} 4-\mathrm{S} 5_{\mathrm{L}}$ mimicking peptides associated with an increased current density. Left: $(\mathbf{A}, \mathbf{C})$ representative western blots of total $\mathrm{Na}_{\mathrm{V}} 1.4$, transferrin receptor (TransR) and GAPDH from transfected COS-7 cells, in the presence of various control and S4-S5 $\mathrm{L}$ peptides as indicated. (B,D) representative western blots of the cell surface fraction of $\mathrm{Na}_{\mathrm{V}} 1.4$, transferrin receptor (TransR) and GAPDH from transfected COS-7 cells, in the presence of various control and $\mathrm{S} 4-\mathrm{S}_{\mathrm{L}}$ peptides. Right: corresponding quantifications of normalized mean \pm sem intensities. Band intensities are first normalized to the intensity of the corresponding TransR bands, and ratios are then normalized to control 1 condition. In all condition, $\mathrm{p}>0.05$. In A-D, the three blots, realized on the same membrane, are cropped. Full-length blots of each tested protein are reported in Supplemental Fig. 5. 


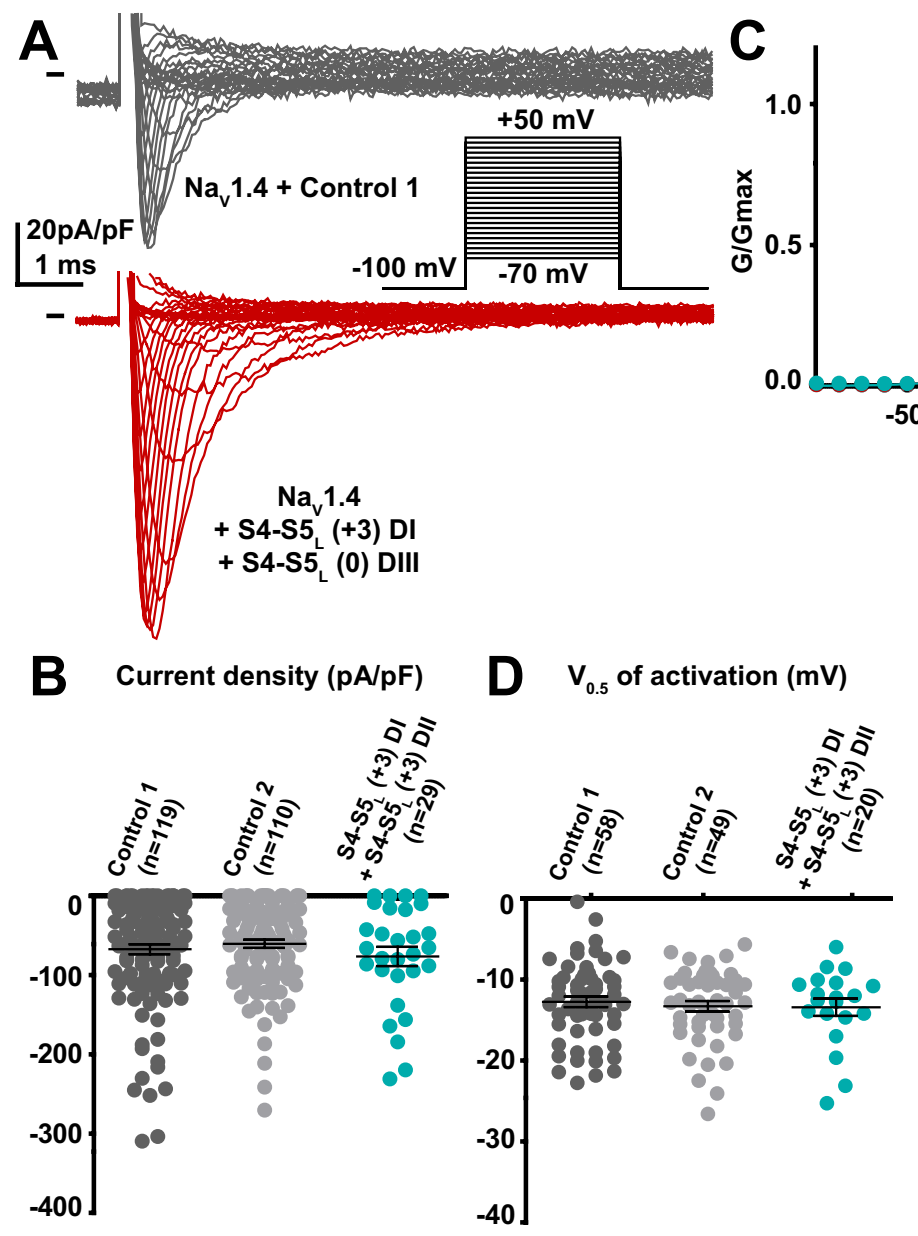

E $K$ of activation $(\mathrm{mV})$
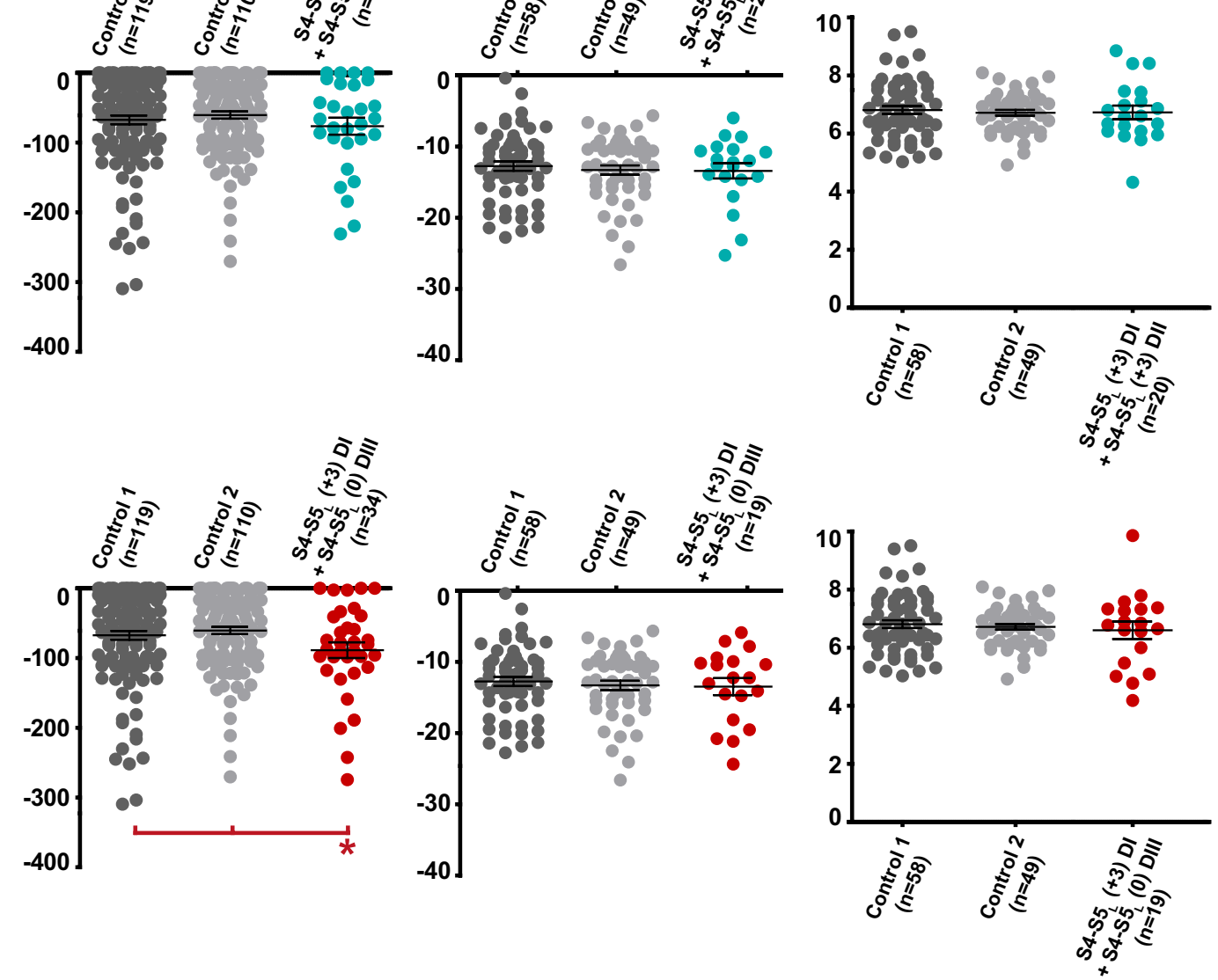

Figure 10. Effect of combination of two $\mathrm{Na}_{\mathrm{V}} 1.4 \mathrm{~S} 4-\mathrm{S}_{\mathrm{L}}$ mimicking peptides that both had an effect on $\mathrm{Na}_{\mathrm{V}} 1.4$ current density when expressed alone. (A) representative, superimposed current recordings in COS-7 cells cotransfected with $\mathrm{Na}_{\mathrm{V}} 1.4, \mathrm{Na}_{\mathrm{V}} ß 1$, and control 1 (top trace) or the combination of domain I S4-S5 $5_{\mathrm{L}}(+3)$ peptide and domain III S4-S5 $5_{\mathrm{L}}(0)$ peptide (bottom trace). Inset: activation voltage protocol used (holding potential: $-100 \mathrm{mV}$; 30-ms pulse; one sweep every $2 \mathrm{~s}$ ). (B) Dot plot and mean \pm sem of peak $\mathrm{Na}_{\mathrm{V}} 1.4$ current densities recorded in COS-7 cells co-transfected with $\mathrm{Na}_{\mathrm{V}} 1.4, \mathrm{Na}_{\mathrm{V}} ß 1$, and the indicated peptides, at $0 \mathrm{mV}$. C: Relative peak conductance versus membrane potential curves for $\mathrm{Na}_{\mathrm{V}} 1.4$ channels in the same cell groups as in (B). Lines are Boltzmann fits to the data. $(\mathbf{D}, \mathbf{E})$ Dot plot and mean \pm sem of $\mathrm{Na}_{\mathrm{V}} 1.4$ half-activation potential $\left(\mathrm{V}_{0.5} ; \mathbf{D}\right)$ and activation slope $(\mathrm{K} ; \mathbf{E})$ in the same cells group as in $(\mathbf{B})$. *p value $v s$. both controls $<0.05$. 


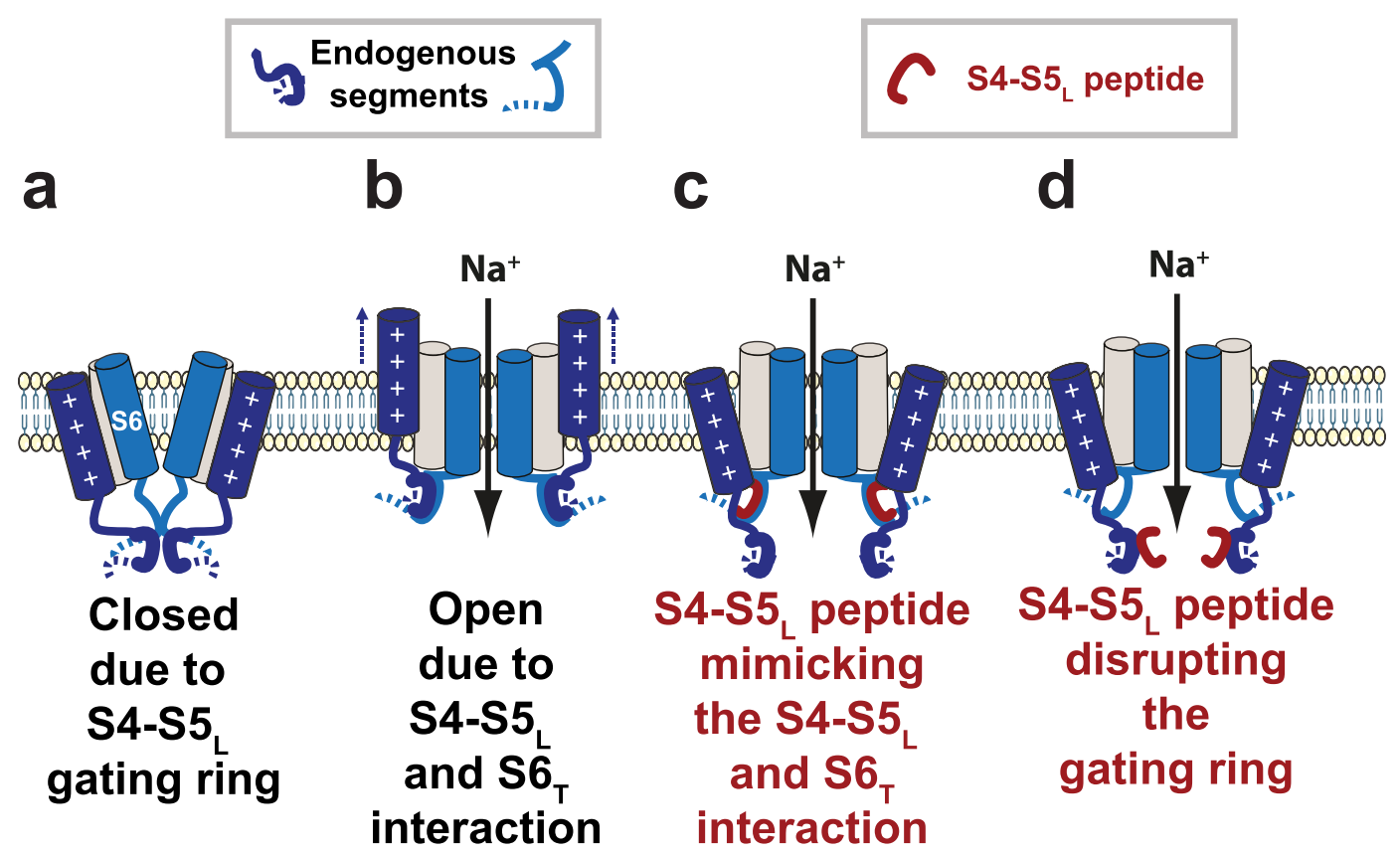

Figure 11. Summarizing schemes. (a,b) Two mechanisms of voltage-dependent gating. (a) The gating ring model in which the four S4-S5 ${ }_{\mathrm{L}}$ (endogenous segments, deep blue, only two are shown) constitute a constriction ring preventing S6 (endogenous segment, light blue) iris-like dilation. (b) Scheme of the ligand/receptor model in which $S 4-S 5_{L}$ binds to $S 6_{T}$ to stabilize the channel in the open state. (c) The $S 4-S 5_{L}$ peptides (red) mimic the effect of endogenous $\mathrm{S} 4-\mathrm{S} 5_{\mathrm{L}}$ described in (b), stabilizing the open conformation. (d) Alternatively, the $\mathrm{S} 4-\mathrm{S} 5_{\mathrm{L}}$ peptides (red), interact with endogenous $\mathrm{S} 4-\mathrm{S}_{\mathrm{L}}$, destabilizing the gating ring described in (a) and hence lead to channel opening.

Because of the moderate peptides effects, we cannot be sure that the ligand/receptor is the major actor of signal transduction between S4 movement and pore opening in $\mathrm{Na}_{\mathrm{V}}$ channels. Other mechanisms such as the constriction ring mechanism, suggested by several $\mathrm{Na}_{\mathrm{V}}$ channels structures, certainly play a major role $\mathrm{e}^{10,12,15,20,21}$. The S4-S5 ${ }_{L}$ peptides may also disrupt the constriction ring and by this way lead to channel opening (Fig. 11d). But the fact that $\mathrm{Na}_{\mathrm{V}} \mathrm{Sp} 1$ most potent peptides contain amino-acids that play a major role in channel open state stabilization (Figs. 3 and 4), strongly supports the hypothesis that these peptides (endogenous or exogenous peptides) bind to the C-terminal end of S6 and stabilize the channel open state (Fig. 11c).

Both mechanisms (Constriction ring in Fig. 11a and ligand-receptor in Fig. 11b) may coexist: the interaction between $\mathrm{S} 4-\mathrm{S} 5_{\mathrm{L}}$ and $\mathrm{S} 6_{\mathrm{T}}$ suggested in the closed state (recent work of Wisedchaisri et al. on the bacterial channel $\mathrm{Na}_{\mathrm{V}} \mathrm{Ab}^{19}$ ) may completely reconfigure in the open state (studies on $\mathrm{NavMs}^{8,16,17}$, and also the present study on $\mathrm{Na}_{V} \mathrm{Sp} 1$ and $\mathrm{Na}_{\mathrm{V}} 1.4$ ). Interestingly, $\mathrm{S} 4-\mathrm{S} 5_{\mathrm{L}}$ residues implicated in the interaction with $\mathrm{S}_{\mathrm{T}}$ in the $\mathrm{Na}_{\mathrm{V}} \mathrm{Ab}$ closed state (highlighted in Supplemental Fig. 3) do not align with the $\mathrm{S} 4-\mathrm{S} 5_{\mathrm{L}}$ residues implicated in the interaction with $\mathrm{S}_{\mathrm{T}}$ in the $\mathrm{Na}_{\mathrm{V}} \mathrm{Ms}$ open state, suggesting the aforementioned reconfiguration of the interaction between S4-S5 linker and $\mathrm{S}_{\mathrm{T}}$. In addition, effects may be moderate because the fast kinetics of $\mathrm{Na}_{\mathrm{V}}$ channel do not give the $S 4-S 5_{L}$ peptides enough time to outcompete the endogenous $S 4-S 5_{L}$ from interacting with $S 6_{T}$.

Regarding peptides effect on $\mathrm{hNa}_{\mathrm{V}} 1.4$, we took the option to co-express the pore-forming subunit with the auxiliary subunit $h \mathrm{Na}_{\mathrm{V}} ß 1$ to be closer to physiological conditions. Because of the presence of $h \mathrm{ha}_{\mathrm{V}} ß 1$, we cannot exclude that peptides effects on $\mathrm{hNa}_{\mathrm{V}} 1.4$ are mediated by this subunit. However, (i) the similitude of the peptide effects independently of the domain (I, II or III), (ii) the absence of domain IV peptide effect and (iii) the similitude of $\mathrm{hNa}_{\mathrm{V}} 1.4$ results to those observed on $\mathrm{Na}_{\mathrm{V}} \mathrm{Sp} 1$ channel, lacking auxiliary subunit, suggest that the effect is rather specific to the pore-forming subunit.

From the present and previous studies, it seems that the coupling between voltage sensor movement and pore gating falls into two categories:

- the mechanical lever model: an obligatory coupling in which S4 resting state directly translates into S6 gate closed state. This obligatory coupling may be described as a simple mechanical work. At rest, S4-S5 linker helices compress the $\mathbf{S 6}$ helices and maintain the pore closed. Upon membrane depolarization, an outward displacement of S4 relieves the compression, allowing pore opening ${ }^{10}$. This model of electromechanical coupling is likely for Shaker-like channels in which open probability is very close to zero at hyperpolarizing potentials ${ }^{22}$;

- the ligand/receptor model: the obligatory coupling cannot hold if the S6 gate is able to open, even if S4 segments are in the resting state, as shown for $\mathrm{hK}_{\mathrm{V}} 11.1$ and $\mathrm{hK}_{\mathrm{V}} 7.1$ channels ${ }^{23,24,35}$. In this case, coupling is allosteric rather than obligatory: in these $\mathrm{K}_{\mathrm{V}}$ channels, $\mathrm{S} 4$ resting state favors rather than forces channel closing. This allosteric coupling is realized through a ligand/receptor mechanism between $\mathrm{S} 4-\mathrm{S} 5_{\mathrm{L}}$ and $\mathrm{S} 6_{\mathrm{T}}$ in 
$\mathrm{hK} \mathrm{V}_{\mathrm{V}} 7.1, \mathrm{hK} \mathrm{K}_{\mathrm{V}} 11.1$ and $\mathrm{hK} \mathrm{V}_{\mathrm{V}} 10.2$ channels ${ }^{25,26,29}$. At rest, $\mathrm{S} 4-\mathrm{S} 5_{\mathrm{L}}$ binds to $\mathrm{S} 6_{\mathrm{T}}$ and stabilizes the channel in a closed state. If $\mathrm{S} 4-\mathrm{S} 5_{\mathrm{L}}$ affinity to $\mathrm{S} 6_{\mathrm{T}}$ is low enough, $\mathrm{S} 4-\mathrm{S} 5_{\mathrm{L}}$ and $\mathrm{S} 6_{\mathrm{T}}$ interaction is not permanent in $\mathrm{S} 4$ resting state, allowing transient pore opening. This is consistent with mutations in $S 4-S 5_{\mathrm{L}}$ and $S 6_{\mathrm{T}}$ increasing the fraction of constitutively active current ${ }^{9,23,35,36}$.

Together, structural studies and the present study suggest that $\mathrm{Na}_{\mathrm{V}}$ channels combine both mechanical lever (obligatory) and ligand/receptor (allosteric) models: (i) Structural data of various $\mathrm{Na}_{\mathrm{V}}$ channel point to an electromechanical (obligatory) coupling model in which the four S4-S5 linkers are organized in a constriction ring that forces the channel gate to close when membrane is polarized. Upon membrane depolarization, movement of the S4 induces a lateral dilation of the S4-S5 linker, leading to a rotation and bending of the pore-lining S6

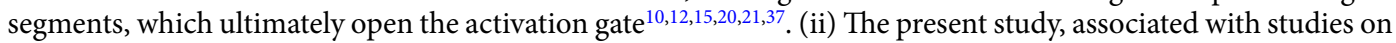
$\mathrm{Na}_{V} \mathrm{Ms}^{8,16,17}$, suggests an allosteric coupling: when S4 segments are in the activated conformation, S4-S5 linkers bind to $S 6_{\mathrm{T}}$ and stabilize the channel in the open state. Various $\mathrm{Na}_{\mathrm{V}} 1.4$ structures, all showing $\mathrm{S} 4$ in the activated state but showing the $\mathrm{S} 6$ gate either closed ${ }^{15}$ or open ${ }^{11,21}$, are consistent with this allosteric mechanism in which $\mathrm{S} 4$, when activated, is not strongly coupled to $S 6_{\mathrm{T}}$, but rather develop interactions with $\mathrm{S}_{\mathrm{T}}$ favoring the channel open state.

Many mutations of the $\mathrm{hNa}_{\mathrm{V}} 1.4$-encoding gene, $S C N 4 A$, are linked to muscular channelopathies ${ }^{38}$. The role of the S4-S5 linker as a modulator of the channel open state is consistent with the identification of several mutations in the area corresponding to the activating peptides: L689F, I692M, I693T in domain II and V1149L, A1152D and P1158S in domain III (underlined in Fig. 1B). Noteworthy, mutations in and around these sites (L689F, I692M, N1151C, A1152C, A1160C, P1158S) impair activation kinetics ${ }^{39-45}$.

Finally, mimicking peptides engineered for $\mathrm{hK}_{\mathrm{V}} 7.1, \mathrm{hK}_{\mathrm{V}} 11.1, \mathrm{hK}_{\mathrm{V}} 10.2$ and now $\mathrm{hNa}_{\mathrm{V}} 1.4$ may lead to a new therapeutic strategy for cardiac, neuronal and muscular channelopathies ${ }^{46}$.

\section{Methods}

Similar methods have been used in previous studies ${ }^{25,26,29}$.

Plasmid constructs. For $\mathrm{Na}_{\mathrm{V}} \mathrm{Sp} 1$ and $\mathrm{hNa}{ }_{\mathrm{V}} 1.4, \mathrm{~S} 4-\mathrm{S}_{\mathrm{L}}$ plasmids were designed from the alignment with $\mathrm{hK}_{\mathrm{V}} 11.1$ and $\mathrm{hK} \mathrm{V}_{\mathrm{V}} 7.1 \mathrm{~S} 4-\mathrm{S} 5_{\mathrm{L}}$ peptides. First, multiple-sequence alignment was realized with Cobalt ${ }^{47}$. This program aligned the predicted/observed S4 and S5 transmembrane domains of hK $\mathrm{V}_{\mathrm{V}} 11.1$ (Uniprot Q12809), hK $\mathrm{V} 7.1$ (P51787), $\mathrm{Na}_{\mathrm{V}} \mathrm{Sp} 1^{14,48}$, and the four domains of $\mathrm{hNa} \mathrm{V}_{\mathrm{V}} 1.4$ (Uniprot P35499). We designed a Na $\mathrm{Sp} 1 \mathrm{~S} 4-\mathrm{S}_{\mathrm{L}}$ peptide and also a $\mathrm{Na}_{\mathrm{V}} 1.4 \mathrm{~S} 4-\mathrm{S}_{\mathrm{L}}$ peptide in each domain, based on the aligned most potent $\mathrm{hK}_{\mathrm{V}} 7.1$ and $\mathrm{hK}_{\mathrm{V}} 11.1$ S4-S5 $\mathrm{L}_{\mathrm{L}}$ peptides, as shown in Fig. $1 \mathrm{~B}^{25,26}$. Since a peptide shifted by three amino acids toward the C-terminus also inhibited $\mathrm{hK}_{\mathrm{V}} 7.1$ (L251-L266), we also selected the corresponding peptide and also the next one in case of slight differences in binding sites. Thus, for $\mathrm{Na}_{\mathrm{V}} \mathrm{Sp} 1$ and each $\mathrm{hNa} \mathrm{V}_{\mathrm{V}} 1.4$ domain, three different $\mathrm{S} 4-\mathrm{S} 5_{\mathrm{L}}$ plasmids were designed. All the peptides had the same length (16 amino-acids). Names of the peptides were given according to their position along the sequence: $\mathrm{S} 4-\mathrm{S} 5_{\mathrm{L}}(-3), \mathrm{S} 4-\mathrm{S} 5_{\mathrm{L}}(0)$, and $\mathrm{S} 4-\mathrm{S} 5_{\mathrm{L}}(+3)$ (Fig. $\left.1 \mathrm{~B}\right)$. Two peptides, corresponding to hKv11.1 S4-S5 linker (A536-F551) and hKv11.1 C-terminus of S6 (I663-T675) were used as two negative controls. Oligonucleotides encoding $\mathrm{hNa}_{\mathrm{V}} 1.4$ and $\mathrm{Na}_{\mathrm{V}} \mathrm{Sp} 1$ peptides were synthesized by TOP Gene Technologies and contained a XhoI restriction enzyme, a methionine (ATG) for translation initiation, and a glycine (GGA) to protect the ribosome binding site during translation and the nascent peptide against proteolytic degradation ${ }^{49}$. A BamHI restriction enzyme site was synthesized at the $3^{\prime}$ end immediately following the translational stop codon (TGA). These oligonucleotides were then cloned into pIRES2-EGFP (Clontech) and sequenced. Mutant $\mathrm{Na}_{\mathrm{V}} \mathrm{Sp} 1$ were generated by using the QuikChange site-directed mutagenesis kit (Stratagene).

Cell culture and transfection. The African green monkey kidney-derived cell line, COS-7, was obtained from the American Type Culture Collection (CRL-1651) and cultured in Dulbecco's modified Eagle's medium (GIBCO) supplemented with $10 \%$ fetal calf serum and antibiotics $(100 \mathrm{IU} / \mathrm{ml}$ penicillin and $100 \mu \mathrm{g} / \mathrm{ml}$ streptomycin) at $5 \% \mathrm{CO}_{2}$ and $95 \%$ air, maintained at $37^{\circ} \mathrm{C}$ in a humidified incubator. Cells were transfected in $35-\mathrm{mm}$ Petri dishes when the culture reached 50-60\% confluence, with DNA ( $2 \mu \mathrm{g}$ total DNA) complexed with FuGENE-6 (Roche Molecular Biochemical) according to the standard protocol recommended by the manufacturer. For $\mathrm{hNa}_{\mathrm{V}} 1.4$ experiments, COS-7 cells were co-transfected with $0.4 \mu \mathrm{g} \mathrm{pRC}-\mathrm{hNa} \mathrm{V}_{\mathrm{V}} 1.4,0.4 \mu \mathrm{g} \mathrm{pRC}-\mathrm{hNa} \mathrm{V}_{\mathrm{V}} ß 1$ (kind gifts of AL George, Northwestern University, Feinberg School of Medicine) and 1.2 $\mu$ g pIRES2-EGFP plasmid (Clontech) encoding control or test peptides. For the experiments with the combination of peptides, COS-7 cells were co-transfected with $0.4 \mu \mathrm{g}$ pRC-hNa $1.4,0.4 \mu \mathrm{g}$ pRC-hNa $\mathrm{V}_{\mathrm{V}} \mathrm{B} 1$ and $0.6 \mu \mathrm{g}$ of each of the two peptides encoding plasmid. For $\mathrm{Na}_{V} \mathrm{Sp} 1$ experiments, COS-7 cells were co-transfected with $0.8 \mu \mathrm{g}$ pIRES2-EGFP-Na $\mathrm{V}_{\mathrm{V}} \mathrm{Sp} 1$ in which EGFP was removed and $1.2 \mu \mathrm{g}$ pIRES2-EGFP plasmid encoding a control or a test peptide. Plasmid quantities were optimized to maximize the quantity of peptides, as assessed by the amount of fluorescence, and to keep current amplitudes in such a range that (i) undetectable currents were rare, and (ii) large currents inducing incorrect voltage-clamp were also rare. In pIRES2-EGFP plasmids, the second cassette (EGFP) is less expressed than the first cassette, guaranteeing high level of peptide expression in fluorescent cells ${ }^{25}$. For experiments with mutant $\mathrm{Na}_{\mathrm{V}} \mathrm{Sp} 1$, COS-7 cells were transfected with $2 \mu \mathrm{g}$ pIRES2-EGFP-Na $\mathrm{V}$ 1. Cells were re-plated onto 35-mm Petri dishes the day after transfection for patch-clamp experiments.

Electrophysiology. The day after splitting, COS-7 cells were mounted on the stage of an inverted microscope and constantly perfused by a Tyrode solution (cf. below) at a rate of $1-3 \mathrm{ml} / \mathrm{min}$. The bath temperature was maintained at $22.0 \pm 2.0^{\circ} \mathrm{C}$. Stimulation and data recording were performed with pClamp 10, an A/D converter (Digidata 1440A) and an Axopatch 200B amplifier (all Molecular Devices). Patch pipettes (tip resistance: 1.5-2.2 
MOhms) were pulled from soda lime glass capillaries (Kimble-Chase) and coated with dental wax to decrease capacitive currents. Currents were acquired in the whole-cell configuration, filtered at $10 \mathrm{kHz}$ and recorded at a sampling rate of $20 \mathrm{kHz}$. Series resistance were compensated to $70-80 \%$. To measure the $\mathrm{Na}_{\mathrm{V}} \mathrm{Sp} 1$ currents, from a holding potential of $-90 \mathrm{mV}$, the membrane was depolarized to $30 \mathrm{mV}$ for $300 \mathrm{~ms}$ every $5 \mathrm{~s}$. $\mathrm{Na}_{\mathrm{V}} \mathrm{Sp} 1$ current was calculated after leak subtraction. To generate the activation curve, from a holding potential of $-90 \mathrm{mV}$, the membrane was depolarized to values between $-60 \mathrm{mV}$ and $+80 \mathrm{mV}$ ( $+10 \mathrm{mV}$ increment) for $300 \mathrm{~ms}$, every $5 \mathrm{~s}$. To measure the $\mathrm{Na}_{\mathrm{V}} 1.4$ current density after complete recovery from inactivation at $-100 \mathrm{mV}$, a single step protocol was used to monitor current increase during recovery. From a holding potential of $-100 \mathrm{mV}$, membrane was depolarized to $0 \mathrm{mV}$ for $30 \mathrm{~ms}$ every $2 \mathrm{~s}$. To generate the activation curve, from a holding potential of -100 $\mathrm{mV}$, the membrane was depolarized to values between $-70 \mathrm{mV}$ and $+50 \mathrm{mV}$ ( $+5 \mathrm{mV}$ increment) for $30 \mathrm{~ms}$, every $2 \mathrm{~s}$. As for $\mathrm{Na}_{V} \mathrm{Sp} 1, \mathrm{Na}_{V} 1.4$ current was calculated after leak subtraction. To generate the inactivation curve, from a holding potential of $-100 \mathrm{mV}$, membrane was depolarized to values between $-110 \mathrm{mV}$ and $+25 \mathrm{mv}(+5 \mathrm{mV}$ increment) for $500 \mathrm{~ms}$, followed by a $20-\mathrm{ms}$ test pulse to $0 \mathrm{mV}$, every $4 \mathrm{~s}$. Activation and inactivation curves were fitted by Boltzmann equations. G/V curves are obtained as follows: $\mathrm{G}_{\mathrm{Na}}$ was calculated from $\mathrm{G}_{\mathrm{Na}}=\mathrm{I}_{\mathrm{Na}} /\left(\mathrm{V}-\mathrm{V}_{\text {rev }}\right)$, where $\mathrm{I}_{\mathrm{Na}}$ is the peak sodium current, $\mathrm{V}$ is the membrane potential and $\mathrm{V}_{\text {rev }}$ is the reversal potential estimated for each cell by linear regression of the linear rectification of I/V curve, when channels are fully activated. GV curves were subsequently obtained by dividing at each potential the peak current by the corresponding value of the linear regression curve.

Solutions. The cells were continuously superfused with a HEPES-buffered Tyrode solution containing (in $\mathrm{mmol} / \mathrm{L}$ ): $\mathrm{NaCl} 145, \mathrm{KCl} 4, \mathrm{MgCl}_{2} 1, \mathrm{CaCl}_{2}$, HEPES 5, glucose 5, $\mathrm{pH}$ adjusted to 7.4 with $\mathrm{NaOH}$. Patch pipettes were filled with the following solution (in mmol/L): KCl 90, Kgluconate 45, $\mathrm{NaCl} \mathrm{10,} \mathrm{HEPES} \mathrm{10,} \mathrm{pH} \mathrm{adjusted} \mathrm{to}$ 7.2 with $\mathrm{KOH}$.

Cell surface biotinylation assays. Surface biotinylation of transfected COS-7 cells (same condition as for patch-clamp experiments) was completed as described previously ${ }^{50}$. Briefly, cells were incubated with $0.5 \mathrm{mg} / \mathrm{ml}$ EZ-Link Sulfo-NHS-SS-Biotin (Pierce) in PBS, pH 7.4, for $30 \mathrm{~min}$ on ice. The biotinylation reaction was quenched with Tris-saline solution $(10 \mathrm{mmol} / \mathrm{L}$ Tris, $\mathrm{pH} 7.4,120 \mathrm{mmol} / \mathrm{L} \mathrm{NaCl})$, and detergent-soluble cell lysates were prepared. Biotinylated cell surface proteins were affinity-purified using Streptavidin-conjugated agarose beads (Pierce), and analyzed by western blot as described previously ${ }^{50}$. Bands corresponding to $\mathrm{hNa}_{\mathrm{V}} 1.4$ were normalized to bands corresponding to TransR from the same sample. $\mathrm{hNa}_{\mathrm{V}} 1.4$ protein expression (total or biotinylated fraction) in cells co-transfected with test peptides is expressed relative to $\mathrm{hNa}_{\mathrm{V}} 1.4$ protein expression (total or biotinylated fraction) in cells co-transfected with Control 1 peptide-encoding plasmid. Antibodies used were anti- $\mathrm{Na}_{\mathrm{V}} \mathrm{PAN}$ mouse monoclonal antibody (Sigma, S8809), mouse monoclonal antibody against the transferrin receptor (Invitrogen, 13-6890), and a mouse monoclonal antibody against GAPDH (Santa Cruz Biotechnology, sc-32233). Anti-mouse horseradish peroxidase-conjugated secondary antibody was purchased from Santa Cruz Biotechnology.

Statistics. All data are expressed as mean \pm sem. Statistical differences between samples were determined using Student's t-tests when data were normally distributed (biophysical parameters) and rank-sum tests (Mann Whitney test) when data were not normally distributed (current densities). A value of $\mathrm{p}<0.05$ versus both controls was considered significant.

Received: 21 June 2019; Accepted: 12 March 2020;

Published online: 03 April 2020

\section{References}

1. Huang, W., Liu, M., Yan, S. F. \& Yan, N. Structure-based assessment of disease-related mutations in human voltage-gated sodium channels. Protein Cell 8, 401-438 (2017).

2. Choveau, F. S. et al. Opposite Effects of the S4-S5 Linker and PIP(2) on Voltage-Gated Channel Function: KCNQ1/KCNE1 and Other Channels. Front. Pharmacol. 3, 125 (2012).

3. Arrigoni, C. et al. Unfolding of a Temperature-Sensitive Domain Controls Voltage-Gated Channel Activation. Cell 164, 922-936 (2016).

4. Bagneris, C. et al. Role of the C-terminal domain in the structure and function of tetrameric sodium channels. Nat. Commun. 4, 2465 (2013).

5. Bagneris, C., Naylor, C. E., McCusker, E. C. \& Wallace, B. A. Structural model of the open-closed-inactivated cycle of prokaryotic voltage-gated sodium channels. J. Gen. Physiol. 145, 5-16 (2015).

6. Ferrer, T., Rupp, J., Piper, D. R. \& Tristani-Firouzi, M. The S4-S5 linker directly couples voltage sensor movement to the activation gate in the human ether-a'-go-go-related gene (hERG) K+ channel. J. Biol. Chem. 281, 12858-12864 (2006).

7. Irie, K., Shimomura, T. \& Fujiyoshi, Y. The C-terminal helical bundle of the tetrameric prokaryotic sodium channel accelerates the inactivation rate. Nat. Commun. 3, 793 (2012).

8. Ke, S., Ulmschneider, M. B., Wallace, B. A. \& Ulmschneider, J. P. Role of the Interaction Motif in Maintaining the Open Gate of an Open Sodium Channel. Biophys. J. 115, 1920-1930 (2018).

9. Labro, A. J. et al. The S4-S5 linker of KCNQ1 channels forms a structural scaffold with the S6 segment controlling gate closure. J. Biol. Chem. 286, 717-725 (2011).

10. Long, S. B., Campbell, E. B. \& Mackinnon, R. Voltage sensor of Kv1.2: structural basis of electromechanical coupling. Science 309, 903-908 (2005).

11. Pan, X. et al. Structure of the human voltage-gated sodium channel Nav1.4 in complex with. Science. 362, beta1 (2018).

12. Payandeh, J., Scheuer, T., Zheng, N. \& Catterall, W. A. The crystal structure of a voltage-gated sodium channel. Nature 475, 353-358 (2011).

13. Sanguinetti, M. C. \& Xu, Q. P. Mutations of the S4-S5 linker alter activation properties of HERG potassium channels expressed in Xenopus oocytes. J. Physiol. 514(Pt 3), 667-675 (1999). 
14. Shaya, D. et al. Structure of a prokaryotic sodium channel pore reveals essential gating elements and an outer ion binding site common to eukaryotic channels. J. Mol. Biol. 426, 467-483 (2014).

15. Shen,H. et al. Structure of a eukaryotic voltage-gated sodium channel at near-atomic resolution. Science 355 (2017).

16. Sula, A. et al. The complete structure of an activated open sodium channel. Nat. Commun. 8, 14205 (2017).

17. Sula, A. \& Wallace, B. A. Interpreting the functional role of a novel interaction motif in prokaryotic sodium channels. J. Gen. Physiol. 149, 613-622 (2017).

18. Tristani-Firouzi, M., Chen, J. \& Sanguinetti, M. C. Interactions between S4-S5 linker and S6 transmembrane domain modulate gating of HERG K+ channels. J. Biol. Chem. 277, 18994-19000 (2002).

19. Wisedchaisri, G. et al. Resting-State Structure and Gating Mechanism of a Voltage-Gated Sodium Channel. Cell 178, 993-1003 (2019).

20. Xu, H. et al. Structural Basis of Nav1.7 Inhibition by a Gating-Modifier Spider Toxin. Cell 176, 702-715 (2019).

21. Yan, Z. et al. Structure of the Nav1.4-beta1 Complex from Electric Eel. Cell 170, 470-482 (2017).

22. Lu, Z., Klem, A. M. \& Ramu, Y. Coupling between voltage sensors and activation gate in voltage-gated K+ channels. J. Gen. Physiol. 120, 663-676 (2002).

23. Ma, L. J., Ohmert, I. \& Vardanyan, V. Allosteric features of KCNQ1 gating revealed by alanine scanning mutagenesis. Biophys. J. 100, 885-894 (2011)

24. Vardanyan, V. \& Pongs, O. Coupling of voltage-sensors to the channel pore: a comparative view. Front. Pharmacol. 3, 145 (2012).

25. Choveau, F. S. et al. KCNQ1 channels voltage dependence through a voltage-dependent binding of the S4-S5 linker to the pore domain. J. Biol. Chem. 286, 707-716 (2011).

26. Malak, O. A., Es-Salah-Lamoureux, Z. \& Loussouarn, G. hERG S4-S5 linker acts as a voltage-dependent ligand that binds to the activation gate and locks it in a closed state. Sci. Rep. 7, 113 (2017).

27. Enkvetchakul, D., Loussouarn, G., Makhina, E. \& Nichols, C. G. ATP interaction with the open state of the K(ATP) channel. Biophys. J. 80, 719-728 (2001).

28. Loussouarn, G. et al. Phosphatidylinositol-4,5-bisphosphate, PIP2, controls KCNQ1/KCNE1 voltage-gated potassium channels: a functional homology between voltage-gated and inward rectifier K+ channels. EMBO J. 22, 5412-5421 (2003).

29. Malak, O. A. et al. Voltage-dependent activation in EAG channels follows a ligand-receptor rather than a mechanical-lever mechanism. J. Biol. Chem. 294, 6506-6521 (2019).

30. Popa, M. O., Alekov, A. K., Bail, S., Lehmann-Horn, F. \& Lerche, H. Cooperative effect of S4-S5 loops in domains D3 and D4 on fast inactivation of the $\mathrm{Na}+$ channel. J. Physiol. 561, 39-51 (2004).

31. Desaphy, J. F. et al. Translational approach to address therapy in myotonia permanens due to a new SCN4A mutation. Neurology 86, 2100-2108 (2016).

32. Tsujino, A. et al. Myasthenic syndrome caused by mutation of the SCN4A sodium channel. Proc. Natl. Acad. Sci. USA 100, 7377-7382 (2003).

33. Kontis, K. J., Rounaghi, A. \& Goldin, A. L. Sodium channel activation gating is affected by substitutions of voltage sensor positive charges in all four domains. J. Gen. Physiol. 110, 391-401 (1997).

34. Chanda, B. \& Bezanilla, F. Tracking voltage-dependent conformational changes in skeletal muscle sodium channel during activation. J. Gen. Physiol. 120, 629-645 (2002).

35. Osteen, J. D. et al. Allosteric gating mechanism underlies the flexible gating of KCNQ1 potassium channels. Proc. Natl. Acad. Sci. USA 109, 7103-7108 (2012)

36. Boulet, I. R., Labro, A. J., Raes, A. L. \& Snyders, D. J. Role of the S6 C-terminus in KCNQ1 channel gating. J. Physiol. 585, 325-337 (2007).

37. Lenaeus, M. J. et al. Structures of closed and open states of a voltage-gated sodium channel. Proc. Natl. Acad. Sci. USA 114, E3051-E3060 (2017).

38. Loussouarn, G. et al. Physiological and Pathophysiological Insights of Nav1.4 and Nav1.5 Comparison. Front. Pharmacol. 6, 314 (2015).

39. Fan, C., Mao, N., Lehmann-Horn, F., Burmann, J. \& Jurkat-Rott, K. Effects of S906T polymorphism on the severity of a novel borderline mutation I692M in Nav 1.4 cause periodic paralysis. Clin. Genet. 91, 859-867 (2017).

40. Trip, J. et al. In tandem analysis of CLCN1 and SCN4A greatly enhances mutation detection in families with non-dystrophic myotonia. Eur. J. Hum. Genet. 16, 921-929 (2008).

41. Yoshinaga, H. et al. Phenotypic variability in childhood of skeletal muscle sodium channelopathies. Pediatr. Neurol. 52, 504-508 (2015).

42. Bouhours, M. et al. A1152D mutation of the $\mathrm{Na}+$ channel causes paramyotonia congenita and emphasizes the role of DIII/S4-S5 linker in fast inactivation. J. Physiol. 565, 415-427 (2005).

43. Popa, M. O., Alekov, A. K., Bail, S., Lehmann-Horn, F. \& Lerche, H. Cooperative effect of S4-S5 loops in domains D3 and D4 on fast inactivation of the $\mathrm{Na}+$ channel. J. Physiol. 561, 39-51 (2004).

44. Ghovanloo, M. R., Abdelsayed, M., Peters, C. H. \& Ruben, P. C. A Mixed Periodic Paralysis \& Myotonia Mutant, P1158S, Imparts pH-Sensitivity in Skeletal Muscle Voltage-gated Sodium Channels. Sci. Rep. 8, 6304 (2018)

45. Plassart-Schiess, E., Lhuillier, L., George, A. L. Jr., Fontaine, B. \& Tabti, N. Functional expression of the Ile693Thr Na+ channel mutation associated with paramyotonia congenita in a human cell line. J. Physiol. 507(Pt 3), 721-727 (1998).

46. Kadam, R. U. et al. Potent peptidic fusion inhibitors of influenza virus. Science 358, 496-502 (2017).

47. Papadopoulos, J. S. \& Agarwala, R. COBALT: constraint-based alignment tool for multiple protein sequences. Bioinformatics. 23, 1073-1079 (2007).

48. D’Avanzo, N. et al. Differential lipid dependence of the function of bacterial sodium channels. PLoS. One. 8, e61216 (2013).

49. Gilchrist, A., Li, A. \& Hamm, H. E. G alpha COOH-terminal minigene vectors dissect heterotrimeric G protein signaling. Sci. STKE. 2002, 11 (2002)

50. Marionneau, C. et al. The sodium channel accessory subunit Navbeta1 regulates neuronal excitability through modulation of repolarizing voltage-gated $\mathrm{K}(+)$ channels. J. Neurosci. 32, 5716-5727 (2012).

\section{Acknowledgements}

We thank Daniel L. Minor, Jr. and Isabelle Baró for careful reading of the manuscript. The project was funded by the Association Française contre les Myopathies - Téléthon (16495), the 7th European Community Framework Programme and the Marie Curie European Actions (PIOF-GA-2011-298280) to Gildas Loussouarn, and the Agence Nationale de la Recherche (ANR-15-CE14-0006-01) to Céline Marionneau. Olfat Malak was laureate of the Line Pomaret-Delalande prize of the Fondation pour la Recherche Médicale (PLP20141031304; FRM). Olfat Malak wishes to personally thank Mrs. Line Pomaret for her generous support. Olfat Malak and Fayal Abderemane Ali were supported by the Fondation Génavie. Fabien Coyan and Fayal Abderemane Ali were recipients of a grant from the French Ministère de la Recherche. We thank Aurore Girardeau and Béatrice Ollivier for their technical support. 


\section{Author contributions}

O.A.M. carried out the patch-clamp experiments on $\mathrm{Na}_{\mathrm{V}} 1.4$ activation. O.A.M., F.A.A., Y.W. carried out patchclamp experiments on $\mathrm{Na}_{\mathrm{V}} 1.4$ inactivation. F.C.C., F.A.A., Y.W. and G.P carried out preliminary test in patchclamp experiments. F.A.A. and D.S. carried out molecular biology of $\mathrm{Na}_{\mathrm{V}} \mathrm{Sp} 1$ channel. O.A.M. carried out the patch-clamp experiments on $\mathrm{Na}_{\mathrm{V}} S$ S1. O.A.M. carried out the western blot and biotinylation experiments, under C.M. supervision. O.A.M. analyzed the patch-clamp and biotinylation experiments. O.A.M. prepared the figures. G.L. wrote the manuscript.

\section{Competing interests}

The authors declare no competing interests.

\section{Additional information}

Supplementary information is available for this paper at https://doi.org/10.1038/s41598-020-62615-6.

Correspondence and requests for materials should be addressed to G.L.

Reprints and permissions information is available at www.nature.com/reprints.

Publisher's note Springer Nature remains neutral with regard to jurisdictional claims in published maps and institutional affiliations.

(1) Open Access This article is licensed under a Creative Commons Attribution 4.0 International License, which permits use, sharing, adaptation, distribution and reproduction in any medium or format, as long as you give appropriate credit to the original author(s) and the source, provide a link to the Creative Commons license, and indicate if changes were made. The images or other third party material in this article are included in the article's Creative Commons license, unless indicated otherwise in a credit line to the material. If material is not included in the article's Creative Commons license and your intended use is not permitted by statutory regulation or exceeds the permitted use, you will need to obtain permission directly from the copyright holder. To view a copy of this license, visit http://creativecommons.org/licenses/by/4.0/.

(C) The Author(s) 2020 